\title{
Overpayment, Financial Distress, and Investor Horizons
}

\author{
Dimitris Andriosopoulos* ${ }^{*}$ Amedeo De Cesari ${ }^{\ddagger}$, Konstantinos Stathopoulos ${ }^{\dagger}$
}

\author{
31 August 2017
}

\begin{abstract}
Firms that follow excessive payout policies (over-payers) have significantly higher financial distress risk and lower survival compared to under-payers, consistent with risk-shifting from shareholders to creditors in distressed firms. All else equal, the presence of institutional investors with long-term investment horizons in a firm is associated with overpayment. A transition analysis indicates the existence of a reciprocal relation between overpayment and financial distress, highlighting the feedback effects between overpayment and distress. In addition, overpayers endure smaller future sales and assets growth, and experience a significant future increase in the overall riskiness of their assets, compared to under-payers.
\end{abstract}

Keywords: payout policy, financial distress, firm survival, institutional investor, over-payers, corporate governance.

JEL Classifications: G23, G32, G33, G34, G35.

We thank Shantanu Banerjee, Michael Brennan, Murillo Campello, Sudipto Dasgupta, Robert Faff, Joan Farre-Mensa, Daniel Ferreira, David Hillier, Aneel Keswani, Mauricio Larrain, Meziane Lasfer, Gyongyi Loranth, Alberto Manconi, Andrew Marshall, Patrick McColgan, Roni Michaely, Dimitris Petmezas, Raghavendra Rau, Karin Thorburn, Nickolaos G. Travlos, participants at the $3^{\text {rd }}$ Paris Financial Management conference, $6^{\text {th }}$ Financial Engineering and Banking Society conference, the 2016 European Finance and Banking Conference, and the 2016 FMA Annual Meeting, as well as seminar participants at the Adam Smith School of Business, Glasgow, Audencia Nantes School of Management, Lancaster University Management School, Strathclyde Business School, Surrey Business School, Swansea University, University of Coventry and University of Sussex for helpful comments. All remaining errors are our own.

Corresponding Author: Amedeo De Cesari, Alliance Manchester Business School, The University of Manchester, Booth Street West, Manchester, M15 6PB, UK (email: amedeo.decesari@ manchester.ac.uk; tel:+441613066403).

"Strathclyde Business School, University of Strathclyde, 199 Cathedral Street, Glasgow, G4 0QU, UK (email: d.andriosopoulos@strath.ac.uk; tel: +441415483892).

†Alliance Manchester Business School, The University of Manchester, Booth Street West, Manchester, M15 6PB, UK (email: k.stathopoulos@ manchester.ac.uk; tel: +441612756863). 


\section{Introduction}

In recent years, there has been an increasing focus by market participants on corporate payout levels. The 2015 record payouts in the US have fueled extensive debate in the financial press $^{1}$ over current corporate payout policies and featured prominently in the recent presidential race, when the Democratic nominee's economic plan focused on excessive corporate buybacks and their impact on long-term investment. ${ }^{2}$ The overarching concern in this debate is that high payouts drain firms of important resources, reducing investment, leading to greater risk and instability in listed firms, which propagates to the financial markets.

In this paper, we argue that in order to understand the impact of large payouts on firm (financial distress) risk, the focus should be on excessive payout policies. It is overpayment ${ }^{3}$ that could lead to a significant reduction in liquid assets and retained earnings, which reduces financial flexibility and increases distress risk (the Reduced-flexibility hypothesis). At the same time, it is well established in the literature that firms with high levels of debt and facing significant financial distress risk have an incentive to transfer wealth from creditors to shareholders through payouts (the Risk-shifting hypothesis) (e.g., Black, 1976; Smith and Warner, 1979; Acharya et al., 2017). These two hypotheses are not mutually exclusive; in fact, they could be linked since, for example, risk-shifting could lead to reduced flexibility. Overall, it

\footnotetext{
${ }^{1}$ See for example "US companies on course to return \$1tn to shareholders in 2015" - Platt and MacKenzie, Financial Times (April 12, 2015); “The amount of cash corporate America is dishing to investors sends a scary signal about the stock market's future" - Udland, Business Insider (July 1, 2016).

${ }^{2}$ See www.hillaryclinton.com/briefing/factsheets/2015/07/24/encourage-long-term-growth/ (accessed December 16, 2016).

${ }^{3}$ Hereafter, we use the terms "excessive payout" and "overpayment" interchangeably.
} 
is reasonable to expect a positive relation between overpayment and financial distress. We investigate this prediction by building a simple model of expected payout based on standard accounting, financial, and market variables to identify over-payers (i.e., firms that pay out more than expected based on our model) and examine their distress risk as well as their future survival compared to under-payers. We then look at the ownership of influential shareholders with strong risk-shifting incentives, i.e., long-term institutional investors, and study its association with overpayment.

Assuming firms have an optimal level of total payout (Lambrecht and Myers, 2012), the difference between the actual and optimal level of payout leads to an underpayment or an overpayment. In the spirit of Opler et al. (1999), we define as excess payout the difference between the actual and the expected level, where the expected payout is based on a number of factors shown in the literature to explain the decision for initiating a payout or changing the level and composition of a payout (e.g., Jagannathan et al., 2000; Fama and French, 2001; Grullon et al., 2002; Grinstein and Michaely, 2005; DeAngelo et al., 2006).

But what leads firms to overpay? To understand the decision to overpay, one needs to refer to the seminal works of Jensen and Meckling (1976) and Galai and Masulis (1976) and the ensuing empirical literature. These studies highlight the notion that shareholders have a growing incentive to extract wealth from debtholders through risk-shifting activities as their firm becomes more levered and distressed. While most prior work has identified asset substitution as the most likely form of risk-shifting (e.g., Eisdorfer, 2008; Gilje, 2016), a distressed firm's shareholders can also engage in overpayment to transfer wealth from creditors (e.g., Smith and Warner, 1979). As Black (1976) argues "There is no easier way for a company to escape the burden of a debt than to pay out all of its assets in the form of a dividend, and leave the creditors holding an 
empty shell" (p. 10). In addition, overpayment may not significantly increase the risk faced by shareholders since they hold an option to strategically default, which can be particularly valuable when shareholders can extract wealth from debtholders conditional on a debt renegotiation taking place (e.g., Davydenko and Strebulaev, 2007; Garlappi et al., 2008; Garlappi and Yan, 2011; Favara et al., 2012).

This wealth transfer effect is empirically supported by the inverse relation between stock price and bond price reactions to the announcement of buyback programs, especially for firms with higher distress risk (Maxwell and Stephens, 2003), and to the announcement of dividends (Dhillon and Johnson, 1994). Similarly, Pryschepa et al. (2013) show that financially distressed firms, which are not yet identified by the market as being distressed, are less likely to reduce their payouts to shareholders, hence, transferring wealth from creditors to shareholders. Acharya et al. (2017) report that US financial institutions with high leverage and comparatively low franchise value (i.e., continuation value) made large and increasing dividend payments during the 2007-2009 crisis.

However, not all shareholders have the same risk-shifting incentives and ability to influence managers' decision to overpay or underpay. The most important class of shareholders, i.e., institutional investors, is a rather heterogeneous group. Long-term institutional investors have the resources and motivation to monitor managers (Harford et al., 2017), and also have a "strong voice" in a firm (Aghion et al., 2013); therefore managers cater to their preferences (Gaspar et al., 2012). Furthermore, these investors hold, on average, well-diversified portfolios (Bushee, 1998; 2001), so they are likely to be rather insensitive to firm-specific risk and are expected to have very strong risk-shifting incentives. In contrast, short-term institutional investors adopt transient trading strategies, hence, have little incentive to monitor managers or 
exercise power through voice. As a result, they have little influence over corporate decisionmaking, particularly investment decisions (Cella, 2014). Since, risk-shifting through payouts can also be costly to shareholders (especially undiversified blockholders) and managers, particularly when the continuation value of the firm is high (e.g., Fan and Sundaresan, 2000; DeMarzo and Fishman, 2007; Acharya et al., 2017), we argue that firms with more influential, well-diversified shareholders, who can and have the incentive to force managers to overpay, are more likely to choose excessive payouts. We rely on this intuition and expect to find a positive association between long-term institutional investor holdings and a firm's likelihood to overpay.

Using the above arguments, we analyze firm-year observations for all publicly listed industrial US firms from 1975 to 2013 and employ a set of variables established in the payout literature to identify firms that pay out more (or less) than expected, where the expected total payout (i.e., dividends plus share repurchases) is estimated by our model. We then classify observations with positive total payouts (i.e., payers) as over-payers or under-payers. ${ }^{4} \mathrm{We}$ recognize that there is no unambiguous model of "expected" payout. Hence, we use several definitions of overpayment to classify our firms. We test whether overpaying is associated with financial distress and reduced firm survival. To do so, we employ a comprehensive set of accounting-based and market-based financial distress, involuntary delisting, and actual

\footnotetext{
${ }^{4}$ In our study, we intentionally focus on firms that may purposely over-pay or under-pay. Since non-payers are inherently different from payers (Fama and French, 2001; DeAngelo et al., 2006) and are characterized by low profitability and retained earnings, they may be constrained in their payout choices owing to binding legal and/or contractual constraints such as covenants. Non-payers also have more valuable growth opportunities than payers, making them less likely to engage in risk-shifting activities. Finally, in our estimations, a non-payer would be mechanically classified as an under-payer, since the expected payout for a non-payer is always positive. Thus, we exclude non-payers from this part of the analysis.
} 
bankruptcy measures. Our findings suggest that overpaying firms are, on average, higher on the financial distress risk spectrum and have a shorter lifespan compared to underpaying firms. Our findings are also economically significant. For example, the average default probability based on Bharath and Shumway's (2008) approximation of Merton's (1974) distance to default model, is $5.31 \%$ for over-payers compared with $2.26 \%$ for under-payers. Admittedly, and in line with our hypotheses (i.e., the Reduced-flexibility and Risk-shifting hypotheses), the direction of causality between overpayment and distress runs both ways. We conduct a transition analysis (Baesel, 1974; Acemoglu and Zilibotti, 1997) confirming the reciprocal relation between overpaying and financial distress.

To further corroborate our conjecture that over-payers' actions are influenced by distress and risk-shifting incentives, we focus on other firm policies relating to growth and risk. In Favara et al.'s (2017) model, distressed firms have incentives to risk-shift through asset substitution (Jensen and Meckling, 1976) and to under-invest (Myers, 1977). Consistent with the predictions of this model, we find that, compared to under-payers, over-payers endure smaller assets and sales growth, and experience significant increases in the overall riskiness of their assets in the first few years after overpaying. This evidence further supports the argument that over-payers are more likely to extract wealth from debtholders and is in line with Chen and Wang (2012) who find that financially constrained firms that repurchase shares reduce their investments.

Having identified those firms that overpay and their association with financial distress and survivability, we turn our focus to the determinants of the decision to overpay. We find robust evidence suggesting that holdings by long-term institutional investors are positively related to the likelihood of overpayment. A one standard deviation increase in the shareholdings of long-term 
institutional investors is associated with a $2.6 \%$ increase in the likelihood of a firm becoming an over-payer. Our finding is consistent with firms catering to their long-term institutional investors by overpaying, even if that translates into higher financial distress. Given that long-term institutional investors have strong risk-shifting incentives, this result is in line with risk-shifting being an important driver of overpayment.

We acknowledge our results may be sensitive to possible misclassification of over-payers and the potential confounding effects driving the relation between overpayment and financial distress. Furthermore, the investment choices of institutional investors could be endogenous to firm payout policy, which could lead to spurious results. We address each of these problems using a series of robustness tests. To avoid misclassifying over-payers, we rely on alternative definitions of an over-payer and our results are qualitatively similar. We also use a range of distress risk measures to account for the confounding effects that can potentially affect the reported relation between overpayment and distress risk, and our results hold. These measures are bound to be affected differently by omitted characteristics, therefore, the fact that we obtain consistent results across these different specifications reduces the probability that some common omitted factor is driving the relation. More importantly, we run a covariate matching method to match over-payers to under-payers, to alleviate concerns of omitted covariate bias, and our results remain unchanged. We also perform a sensitivity analysis for the potential impact of unobserved bias on our covariate matching (Rosenbaum, 2002) and our main results hold.

In order to mitigate the impact of endogeneity in the institutional investor-payout relation, we follow the extant literature (e.g., Cremers and Petajisto, 2009; Harford et al., 2017) and use the holdings of quasi-indexer institutional investors to confirm our findings. Quasi-indexers are typically passive, long-term investors who do not self-select into particular investments based on 
firm characteristics, e.g., payout policy, given that they have to mimic an index. Because of their inability to actively shift their portfolios they have strong incentives to affect firm policy (Appel et al., 2016). We find that the presence of quasi-indexer institutional investors is associated with overpayment. A one standard deviation increase in ownership by quasi-indexers is associated with an increase in the probability of a firm becoming an over-payer by approximately $8.5 \%$. This is consistent with the effect of the presence of dedicated (long-term) investors, which is also associated with an increase in the likelihood of a firm becoming an over-payer. In particular, a one standard deviation increase in ownership by dedicated investors is associated with an increase in the likelihood of overpaying by $2.5 \%$. Our results, support Appel et al. (2016) who argue that passive investors, even though they cannot "vote with their feet" and exit investments, still have a "voice" and influence firms' decisions. Given that our findings remain for dedicated investors and are confirmed for quasi-indexers, we argue that our main results do not appear to be driven by investors self-selecting into investing in overpaying firms.

\section{Sample and data}

\subsection{Sample}

We construct our sample by including all publicly traded US firms in the Center for Research in Security Prices (CRSP) / Compustat merged (CCM) database between 1975 and 2013. Following the extant literature, we exclude financial firms (SIC codes 6000-6999), utilities

(SIC codes 4900-4949), and securities other than common stock. We define dividends as the dollar value of common dividends (Compustat item DVC). Share repurchases are estimated as the purchase of common and preferred stock (Compustat item PRSTKC) minus the reduction in the book value of preferred stock (Compustat item PSTKRV). Total payout is estimated as the sum of dividends and repurchases. Consistent with prior studies (e.g., Dittmar, 2000; Desai and 
Jin, 2011; Leary and Michaely, 2011; Bonaimé et al., 2014), we scale payouts by market capitalization. We consider market capitalization to be preferable to the book value of total assets or earnings since our objective is to reliably identify companies that provide comparatively larger or smaller payouts. Compared to book values, market capitalization reflects relevant information in a timelier manner, including information on intangible assets. Earnings are problematic since they can also be negative, in which case the payout variable cannot be defined. ${ }^{5} \mathrm{CCM}$ also contains the information we need to construct all firm level control variables, other than institutional ownership. In addition, we use the dividend premium from Kulchania (2013) estimated as the annual difference of the logarithms of the average market-tobook $(\mathrm{M} / \mathrm{B})$ ratios between dividend payers and non-payers, which is consistent with the definition in Baker and Wurgler (2004). The total payout estimation sample extends until 2008 to allow for the analysis of a firm's delisting and bankruptcy probability over a leading five-year period on a rolling basis, with 2013 being the final year of the analysis. We obtain information on delisting events from CRSP and data on Chapter 7 and Chapter 11 bankruptcy filings mainly

\footnotetext{
${ }^{5}$ One criticism regarding the use of market capitalization as a denominator in the payout variable is that market prices are volatile and could be affected by market-wide, rather that firm-specific, events. Depreciation in a firm's stock price could lead to a significant increase in the value of the payout variable, possibly leading to the firm's classification as an over-payer. However, we note that (a) a firm that does not change its payout policy in the face of significant macro events could be rightly classified as an over-payer, (b) our classification of persistent over-/underpayers deals with the impact of temporary/idiosyncratic events, and (c) we use other denominators as well and our results remain unchanged (see Section 3 for more details).
} 
from Thomson SDC Platinum. ${ }^{6}$ The final sample consists of 76,392 firm-year observations comprised of 11,510 unique US industrial firms between 1975 and 2008.

For the institutional ownership data we use the universe of the Thomson-Reuters Institutional Holdings (13F) database to collect quarterly institutional holdings during the 19812008 period. Thomson-Reuters collects information contained in the Form 13F proxy statements filed with the Securities and Exchange Commission (SEC). All institutional investors with \$100 million or more in assets under management are required by law to file the $13 \mathrm{~F}$ form with the SEC. The Thomson-Reuters data help us not only to calculate ownership levels for different institutional investor classifications but also to construct the investor turnover measures used in Gaspar et al. (2005; 2012) for capturing institutional investors' investment horizons. In order to enhance the information on institutional investor types and investment styles, we merge the $13 \mathrm{~F}$ data with Brian Bushee's institutional investor classifications. ${ }^{7}$ All relevant variables included in this paper are defined in the Appendix.

\subsection{Descriptive statistics}

Figure 1 shows the historical trends of average corporate payouts scaled by market capitalization. We observe that total corporate payouts declined during the early 1980s, 1990s, and 2000s. Since 2003, total payouts have an upward trend surpassing the historical highs of the late 1970s. Moreover, dividends have declined steadily over most of our time-series, stabilizing toward the late 2000s, with share repurchases driving corporate payouts in recent years. In terms

\footnotetext{
${ }^{6}$ We thank Kevin Aretz for providing a comprehensive baseline dataset of bankruptcy filings based on Thomson SDC Platinum data and complementary information from the Web. We rely on Thomson SDC Platinum and Lynn LoPucki's website (http://lopucki.law.ucla.edu) to extend and update this dataset. However, we do not have information on filings that took place before the ' $80 \mathrm{~s}$.

${ }^{7}$ Available at http://acct.wharton.upenn.edu/faculty/bushee/IIclass.html.
} 
of ownership (Figure 2), institutional investors show a persistent increase in their shareholdings, though the holdings of dedicated institutional investors have remained relatively stable since 1981. Meanwhile, the turnover of institutional investors has declined from a high of approximately 0.22 in 1983 to 0.15 in 1990, after which it peaked at approximately 0.23 and 0.22 in 1996 and 2007 respectively. The difference between the highest and lowest average turnover rates during our time-series (i.e., 0.23-0.15) indicates significant changes in institutional investor attitudes toward their investment horizons over the years. ${ }^{8}$

\section{[Insert Figures $1 \& 2$ about here]}

Table 1 provides the summary statistics for the main variables ${ }^{9}$ used in this paper. Panel A shows that across our sample period firms pay out every year on average approximately $2.3 \%$ of their market capitalization to their shareholders. The average firm in our sample has a leverage ratio of $0.18,12 \%$ of assets in cash, a market-to-book ratio of 1.7 , and has been publicly trading for an average of 15 years. Interestingly, while the average firm has positive cash flows (a mean of 0.08$)$, the average retained earnings are negative at -0.12 .

\section{[Insert Table 1 about here]}

In order to assess financial distress we employ a comprehensive array of established accounting-based and market-based measures. Panel B reports the descriptive statistics of the

\footnotetext{
${ }^{8}$ The 0.08 difference in turnover rates translates to a difference of around 14 months to the average holding period, which is significant considering that the unconditional average holding period is 31 months (i.e., $0.1925 / 2=9.62 \%$ of the portfolio is turned over in a quarter (or $38.5 \%$ in a year); thus, the average holding period for a stock is $12 / 0.385=31$ months $)$

${ }^{9}$ In order to mitigate the impact of outliers that can be particularly large in our dataset, all variables, with the exception of binary variables, are winsorized at the $1 \%$ and $99 \%$ tails.
} 
financial distress measures we use in this study. Increases in the variables Zmijewski-score, $O$ score, Default probability, CHS-score, and Default probability $(\mathrm{CHS})$ indicate higher financial distress. In contrast, Interest coverage, Z-score - Dummy, and Distance to default are inverse financial distress measures. The average firm in our sample is not financially distressed, as amply illustrated by all our financial distress measures. For example, the accounting-based Interest coverage (O-score) ratio is approximately $2.17(-3.76)$. In addition, the average $Z$-score - Dummy ${ }^{10}$ of our sample is 0.84 , which is similar to Brockman et al. (2010), and indicates that $84 \%$ of firm-years in our sample are classified as non-financially distressed. Our market-based measures also point to the same conclusion. Consistent with Bharath and Shumway (2008), we estimate Merton's (1974) distance to default and respective default probability; the average distance to default is 6.42, similarly to Chava and Purnanandam (2010) and Anantharaman and Lee (2014). Following Conrad et al. (2014), we also estimate Campbell et al.'s (2008) CHSscore and associated default probability (CHS) with the mean values being -6.92 and 1.96 respectively.

In order to examine a firm's mortality and survival in relation to its payout, we consider both voluntary and involuntary delistings as well as Chapter 7 and Chapter 11 bankruptcy filings over a five-year period following year $t$ in our sample firms. We follow Bhattacharya et al. (2015) for classifying delistings as voluntary and involuntary. For voluntary delistings, we assess the payout policies for firms that are involved in (a) mergers and acquisitions and (b) exchange transactions. For involuntary delistings, we assess the payout policies for firms that are (c)

\footnotetext{
${ }^{10}$ Following Brockman et al. (2010) and Pryschepa et al. (2013) we use the Z-score - Dummy which is a binary variable that equals one if Altman's (1968) Z-score is higher than 1.81 and zero otherwise. We do this due to the skewness of the distribution of the Altman's Z-score in our sample.
} 
liquidated, where firms are forced to cease operations and sell their assets; (d) dropped from a stock exchange, where firms are dropped for reasons other than liquidation or voluntary delisting and (e) a combination of firms that are liquidated or dropped from the exchange. The average voluntary delisting probability over a five-year period due to mergers and exchange transactions is $18.73 \%$ and $0.97 \%$ respectively. However, given that the focus of our study is on involuntary delistings, the probabilities on Liquidation and Exchange dropped are more important to us. The average probability of liquidation and dropping from the exchange is $0.27 \%$ and $13.79 \%$ respectively over a five-year period, with the combined group being at $14.06 \%$ over the period 1975 to 2013. Finally, the average probability of a bankruptcy filing is significantly smaller and amounts to around $4.9 \%$.

As shown in Panel C, during our sample period, institutional investors have an average ownership of $34.66 \%$ with a mean portfolio turnover of 0.19 (or 31 months), similar to that reported in Gaspar et al. (2012) and Derrien et al. (2013). When splitting institutional investors based on their investment horizons we see that institutional ownership is mostly driven by midand high-turnover investors with an average ownership of $15.3 \%$ and $12.47 \%$ respectively. Moreover, dedicated institutions hold on average $4.78 \%$, though it is the quasi-indexing institutional investors that hold significant ownership positions (22\%) in the average firm.

\section{Identifying over-payers and under-payers}

We employ a standard Tobit model to identify the expected payout based on a set of established variables commonly used in the literature (e.g., Fama and French, 2001; Grinstein and Michaely, 2005; DeAngelo et al., 2006). We then use both the expected and actual payout levels to identify firm-years with higher than expected (over-payers) and lower than expected (under-payers) payouts. While our payout model is estimated using observations for both payers 
(i.e., firms with positive payouts) and non-payers, we only consider payers when creating our two sub-samples of over- and under-payers.

This choice is motivated on several grounds as briefly explained in footnote 4. In particular, we find that non-payers have significantly lower profitability and retained earnings than payers (untabulated). The average for the latter variable is negative for non-payers and positive for payers. Therefore, a significant fraction of non-payers may be forced to follow a zero-payout policy owing to binding legal (e.g., Mansi et al., 2009) and/or contractual constraints such as covenants. Thus, the managers of these firms are likely to have little discretion over payout policy, which reduces the usefulness of these observations in our context. Furthermore, non-payers are smaller and have more valuable growth opportunities, measured by the marketto-book ratio, than the payers (Fama and French, 2001; DeAngelo et al., 2006), that they would lose in case of bankruptcy. Hence, they are far less likely to carry out risk-shifting activities (e.g., Acharya et al., 2017), which are the focus of our study. Finally, in our estimations, a non-payer would be mechanically classified as an under-payer since the expected payout for a non-payer is always positive. It is more meaningful to study those firms that deliberately decide to choose comparatively low payouts.

The prior literature on payout policy has clearly identified a set of determinants that explain the variation in the magnitude of payouts to a large extent and in a robust way. A firm's cash distribution is positively related to the firm's profitability, cash holdings, retained earnings, size, and age, while risk and growth opportunities should be negatively associated with payouts. Leverage could also be relevant as a payout determinant. In our model of expected total payout we consider these well-established determinants to build a reliable model. An additional benefit of using variables that are well established in the literature is that it allows us to avoid data- 
mining and reporting findings that are heavily reliant on arbitrary and questionable choices of payout determinants. Overall, we rely on the following model:

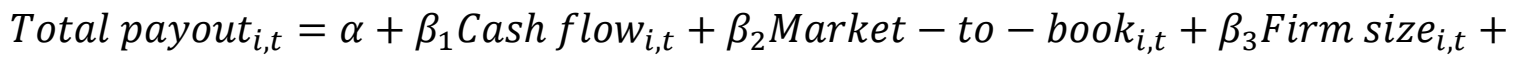
$\beta_{4}$ Leverage $_{i, t}+\beta_{5}$ Retained earning $_{i, t}+\beta_{6}$ Cash holding $_{i, t}+\beta_{7}$ Idiosyncratic risk $_{i, t}+$ $\beta_{8}$ Systematic risk $_{i, t}+\beta_{9}$ Firm age $_{i, t}+u_{i, t}$

where Total payout is total payout over market capitalization. As explained in Section 2.1, we rely on market capitalization as the denominator of our payout variable in order to identify overand under-payers in a precise and timely manner.

However, as highlighted in footnote 5 , market capitalization is affected by stock market fluctuations that could drive our findings, rather than deliberate choices on payout policy. ${ }^{11}$ In untabulated robustness tests, following Michaely and Qian (2017), we repeat all our analyses by requiring that a firm can be classified as an over-payer (under-payer) in a particular year only if it makes total payouts that are larger (smaller) than expected based on a similar model for total payout scaled by book equity. Similarly, we consider total payout models in which payouts are scaled by earnings or with an unscaled log-payout as the dependent variable. We also augment our set of controls with the inclusion of the stock return over the past year in order to capture the impact of recent stock market fluctuations on market capitalization. Overall, we obtain qualitatively similar findings. Furthermore, all our results remain qualitatively similar when we

\footnotetext{
11 We note that, in our sample, $73 \%$ of over-payers increased their total payout (unscaled) during the year by a median increase of $16.6 \%$. This fraction was significantly smaller (65\%) for under-payers which increased their total payout (unscaled) during the year by a median increase of $3.71 \%$. Thus, over-payers appear to deliberately increase their payouts and are not classified as such primarily due to changes in market capitalization.
} 
replace total payout with dividends or repurchases in Model (1). We also replicate the analysis of this model with one year lagged control variables and the results remain unchanged.

The payout determinants we use are: Cash flow estimated as operating income divided by total assets; Market-to-book estimated as firm market value over total assets; Firm size which is the natural log of inflation-adjusted market capitalization; Leverage defined as long-term debt over firm market value; Retained earnings deflated by total assets; Cash holdings calculated as cash and short-term investments over total assets; Idiosyncratic risk estimated as the standard deviation of the residuals of a regression of the daily stock returns in excess of the risk free rate on the value-weighted market return; Systematic risk defined as the standard deviation of the predicted value of a regression of the daily stock returns in excess of the risk free rate on the value-weighted market return; and Firm age calculated as the number of years from a firm's first appearance in CRSP. Finally, we control for the 49 Fama-French industries and year fixed effects, while the standard errors are clustered at the firm level. The results in Table 2 show that larger, lower growth and more mature firms, with higher cash and retained earnings levels, pay out more to their shareholders. In addition, we find that firms with lower risk, both idiosyncratic and systematic risk, make larger payouts consistent with Rozeff (1982) who finds an inverse relation between payout level and a firm's systematic risk.

\section{[Insert Table 2 about here]}

If firm $i$ makes no payout in year $t$ we classify it as a non-payer. Based on the Tobit estimations on the expected and actual payouts, we classify each firm as an over-payer or underpayer. For instance, if the residual $\mathrm{u}_{\mathrm{i}, \mathrm{t}}$ is positive then we classify firm $i$ at year $t$ as an over-payer and if it is negative we classify that firm as an under-payer. Based on this classification method (Mid-point classification) some firms may be marginally classified as over-payers or under- 
payers by construction. To ensure our results are robust we use an alternative classification method as well that is based on terciles (Terciles classification). In particular, we split the set of observations into equal terciles based on the model residuals and classify them into three main categories: under-payers, moderate-payers, and over-payers. Meanwhile, firms that make no payouts at year $t$ are still classified as non-payers. A firm may pay more than expected only once, either by miscalculation or deliberately; however, we wish to identify deliberate over-payers. Therefore, we further ensure our results are robust and not driven by possible misclassification, by classifying our sample firms based on the consistency of their payout policy (Persistent classification). Specifically, if a firm is identified by the Tobit estimations for three consecutive years as having the same relation between actual and expected payout, we classify it into each of the following four categories: consistent non-payers, consistent under-payers, consistent overpayers, and other payers (unclassified) which includes all remaining observations.

Our classifications appear to map real cases quite well. For example, Dell Corp. appears in our analysis as a persistent over-payer. For a number of years before turning private in 2013, Dell poured billions of dollars into its extensive stock repurchase programs leading the way for similar behavior in the tech sector. It was consistently and heavily criticized for it. ${ }^{12}$

Typically, firms that make payouts tend to be larger, more profitable, less risky, older, and have lower growth (Fama and French, 2001; Grullon and Michaely, 2002; DeAngelo et al., 2006; Hoberg and Prabhala, 2009). Our Tobit estimations of Table 2 fully confirm these empirical regularities for the level of total payout. Thus, one might expect that among payers firms that overpay share the same characteristics with firms that tend to make payouts; however, this is not generally the case in our sample. We find that a number of large, mature, and established firms

\footnotetext{
${ }^{12}$ See for example: “The problem with buybacks, Dell edition" - Salmon, Reuters (September 4, 2012).
} 
tend to underpay, while other similar firms tend to overpay. For instance, companies such as Walmart, Procter and Gamble, and 3M always underpay while other established and mature firms such as Nike, DuPont, General Mills, Conagra, McDonalds, Pepsi Co, Coca Cola Co, and Chevron are identified as under-payers in most years. There are other cases such as Merck, Verizon, Northrop Grumman, Heinz, and Intel that sometimes overpay but other times underpay. Finally, firms such as Cisco, Moody's, AT\&T, and Home Depot always overpay.

More importantly, when evaluating the characteristics of over-payers, we do not find any clear patterns traditionally associated with payout policy. As reported in Panel A of Table 3, while, as one might expect, over-payers have fewer growth opportunities as proxied for by lower Market-to-book, larger cash holdings, and less systematic risk, they are also less profitable, smaller and younger, and characterized by lower retained earnings, more leverage, and higher idiosyncratic risk. Thus, our method does not merely identify firms that engage in large payouts, but allows us to study firms that choose payouts that appear excessive.

Panel B of Table 3 provides the average actual and expected payout yields for each classification of non-payers, moderate/unclassified-payers, under-payers, and over-payers. Our focal point is over-payers and under-payers. The results show that firms classified as underpayers pay out significantly less than expected, especially for the Terciles classification in which the payout yield of the average under-payer is less than half its expected payout. Moreover, the average expected payout for under-payers is significantly higher than that for over-payers. In spite of this, over-payers pay out more than double the expected payout level. Overall, these findings suggest that over-payers are firms that make payouts that are particularly large and significantly higher than the payouts that we would expect based on their characteristics. 
It is important to reiterate here that over-payers need not be high payout firms, even though this appears to be the case for the average over-payer in our sample, as reported in Panel B of Table 3. Over-payers should simply have an actual payout yield above the estimated expected one. In untabulated analysis, we identify firms with above median payout yields and compare them with firms with below median payouts. Consistent with prior literature, we find that above median payout firms appear to be less distressed along several dimensions, i.e., they have a higher Z-score - Dummy, lower O-score, and lower probabilities of being delisted and filing for bankruptcy.

\section{[Insert Table 3 about here]}

\section{Over-payers, financial distress, and firm survival}

Based on prior literature (e.g., Chen and Wang, 2012), we anticipate higher than expected payouts to be damaging to firms since they reduce financial flexibility and, ultimately, increase financial distress (the Reduced-flexibility hypothesis). At the same time, firms that are financially distressed may engage in large cash distributions in order to transfer wealth from creditors to shareholders (the Risk-shifting hypothesis) (Black, 1976; Smith and Warner, 1979; Acharya et al., 2017). These two mechanisms are not mutually exclusive and could reinforce each other, possibly through feedback effects. Overall, we expect over-payers to be more financially distressed than under-payers. We investigate our conjecture below.

Table 4 reports the results from the univariate analysis of several financial distress measures across different classifications of firms: non-payers, moderate/unclassified payers, under-payers, and over-payers. The focus of our analysis is on comparing financial distress between over-payers and under-payers; however, we tabulate the differences between overpayers and non-payers for completeness. 


\section{[Insert Table 4 about here]}

The results for the Mid-point classification show that across all measures over-payers have statistically significantly higher financial distress compared with under-payers. Over-payers are characterized by significantly higher values for the variables Zmijewski-score, O-score, Default

probability, and Default probability (CHS), whereas the average values for Interest coverage and Z-score - Dummy are lower for over-payers. In addition, over-payers are on average 3\% more likely to default, having more than twice the average Default probability (5.3\%) compared to under-payers (2.3\%). The same findings apply when classifying firms into terciles and when using the Persistent classification. Overall, we find consistent evidence suggesting that overpayers are higher on the financial distress spectrum.

\section{[Insert Table 5 about here]}

Since over-payers are more financially distressed, we assess whether overpaying firms are more likely to delist and be subject to bankruptcy filings compared to underpaying firms. The univariate tests in Table 5 show that overpaying firms are more likely to merge over a five-year period following the payout compared to under-payers. The results also show that non-payers, on average, delist and drop from the exchange more frequently compared to firms making payouts, which is expected as non-paying firms are typically smaller, riskier, and have higher growth, as opposed to firms making payouts (Fama and French, 2001; DeAngelo et al., 2006). Most importantly though, the results show that it is significantly more common among over-payers to be forced into liquidation or have their stock dropped from the exchange compared to underpayers. This suggests that over-payers are more likely to involuntarily delist (Bhattacharya et al., 2015) and therefore have on average a shorter lifespan as listed firms. In line with this finding, 
the probability of a bankruptcy filing is also significantly larger for over-payers than for underpayers.

In summary, the evidence shows that firms which overpay are more financially distressed, and are more likely to involuntarily delist and be involved in a bankruptcy case over a five-year period following the excess payout. This finding is consistent both with the notion that particularly large payouts may be detrimental to firms (the Reduced-flexibility hypothesis) and with the argument that distressed firms may have an incentive to risk-shift through payouts (the Risk-shifting hypothesis). In Section 6 below, we attempt to disentangle these two non-mutually exclusive hypotheses through a transition analysis.

\section{Covariate matching tests}

A potential weakness of the univariate tests in the previous section stems from the fact that over-payers are inherently different from under-payers and these differences may drive the relation between overpayment and distress. In particular, the residual from Model (1) is a function of both the actual and the expected payout, with the latter variable reflecting firm characteristics that may also be associated with financial distress. To control for differences in observables that could bias our findings, we match each observation for an over-payer (treated observation) with a suitable observation for an under-payer (untreated observation).

We use the Mid-point classification as this allows for a larger sample size and time-variant shift from overpaying to underpaying. Nevertheless, the results based on the other two classifications, i.e., terciles and persistent, are qualitatively similar. We exclude from the sample of untreated observations those firm-years with zero total payouts. We match each firm-year observation identified as an over-payer with an under-payer by using a one-to-one nearest neighbor covariate matching method with replacement and based on the expected level of payout 
as the matching variable. Alternatively, we repeat the matching process based on the similarity of the firm-specific characteristics (all controls), relying on the non-binary independent variables from Table 2. Since payers are inherently different from non-payers (Fama and French, 2001; DeAngelo et al., 2006), we match our treatment and control firms based on observable information available in capital markets but conditional on these firms making a payout. Therefore, and similarly to the argument by von Eije et al. (2014), our matched control firms have ex ante the same likelihood to over-pay as the firms that actually over-pay and vice versa. Given that our treatment and control firms are virtually indistinguishable in terms of observable characteristics, we argue that significant differences in financial distress and firm survival between over-payers and under-payers after matching could be attributed to the treatment effect, i.e., overpayment.

The results in Table 6 show there is a significant reduction in bias ${ }^{13}$ owing to the matching procedure, indicating that the matching technique we use is particularly successful in reducing the differences in observable firm characteristics between the two samples of treated and untreated observations. The bias after matching is only 0.001 when matched based on the expected payout (Panel A) and 2.425 or lower based on all controls (Panel B). Thus, in all cases the absolute bias after matching is well below the recommended threshold (i.e., 5). Moreover, except for Interest coverage and Bankruptcy $($ year +5$)$ in Panel B, the results show that the treatment effect of overpaying has a consistent and positive effect on financial distress, the likelihood that a stock is forced to be delisted from a stock exchange, and the probability of a bankruptcy event.

\footnotetext{
${ }^{13}$ We rely on the Stata user-command psmatch2 to produce our covariate matching estimations and statistics on the bias before and after matching.
} 
Still, the reported average treatment effects can be affected by hidden bias due to unobservable characteristics. Therefore, we assess the sensitivity of our treatment effect (overpayers) on the outcome (financial distress) to hidden bias by employing the Rosenbaum bounds ${ }^{14}$ (Rosenbaum, 2002, 2005, 2010) which are denoted with the $\Gamma$ parameter, a measure of relative odds of treatment or control (Rosenbaum, 2002). $\Gamma=1$ assumes there is no hidden bias and that firms have equal odds of being assigned between the treatment and control groups. When $\Gamma$ is higher than 1, firms have unequal probabilities of being assigned to the treatment and control groups (i.e., over-payers and under-payers) suggesting there is hidden bias. By relaxing the assumption of $\Gamma=1$, it is possible to estimate the extent of hidden bias that can affect the model estimates by increasing the level of the $\Gamma$ parameter (Rosenbaum, 2002). As a result, smaller values of $\Gamma$ indicate that the findings have greater sensitivity to hidden bias. In contrast, higher values of $\Gamma$ indicate that the results have lower sensitivity to hidden bias, therefore, are more robust estimates. For instance, when $\Gamma=2$ it means that a matched control firm is twice as likely to receive the treatment due to hidden bias. ${ }^{15}$

The last column of Table 6 reports the $\Gamma$ values of the Rosenbaum Bounds at the $90 \%$ confidence level. The results show that after matching treated and untreated firms based on their firm-specific characteristics, the impact of overpayment on Interest coverage and Bankruptcy $(y e a r+5)$ is sensitive to hidden bias with $\Gamma$ values of 1.07 and 1.04 respectively. Thus, the only

\footnotetext{
${ }^{14}$ We rely on the Stata user-commands rbounds (Gangl, 2004) for continuous outcomes and mhbounds (Becker and Caliendo, 2007) for binary outcomes.

15 It should be noted that the Rosenbaum Bounds sensitivity tests are inherently very strict. This is because they assume a near perfect and almost deterministic relation between the unobservable covariate(s) (hidden bias) and the outcome, in our case financial distress.
} 
two findings in Table 6 that are inconsistent with our underlying premise are difficult to interpret since they appear susceptible to hidden bias. In contrast, the results on the remaining measures of financial distress are more robust as they are broadly less sensitive to hidden bias. For instance, the $\Gamma$ value for Default probability $(C H S)$ is 1.62 , suggesting that the treatment effect of overpaying on this variable becomes statistically insignificant if an unobserved covariate could alter the likelihood of an untreated firm becoming a treated firm by approximately $62 \%$ (or 1.62 times) resulting in a shift in the log odds ratio of $61.40 \% / 37.90 \%(=1.62)$. Similarly, the $\Gamma$ values for $O$-score show that the hidden bias would need to shift the probability of an untreated firm being classified as a treated firm by $25 \%$ (or 1.25 times) in order to invalidate the statistical significance of overpayment on $O$-score. Overall, this non-parametric quasi-experimental analysis shows that overpayment is associated with higher financial distress and risk of involuntary delisting, and these findings are not likely to be driven by hidden bias due to unobservable characteristics.

\section{[Insert Table 6 about here]}

\section{Transition matrix analysis}

In this section, we turn our attention to the issue of the directionality of the overpayment and financial distress relation. This allows us to (a) build some inferences on possible feedback effects of distress on overpayment and (b) highlight the possible complementarities between the

Reduced-flexibility and Risk-shifting hypotheses. We attempt to tackle this issue by using a transition matrix analysis where each row shows the probability of transitioning from a given state of financial distress and payout, respectively. 
Table 7 reports the transition probabilities across the financial distress spectrum ${ }^{16}$ for under-payers and over-payers respectively. Panel A of Table 7 shows that over-payers experience an increase in financial distress compared to under-payers. In particular, over-payers have a lower probability $(21.82 \%)$ of moving from financial distress $(Z$-score - Dummy $=0)$ to financial health $(Z$-score - Dummy=1) as opposed to under-payers $(31.24 \%)$, with $78.18 \%$ of over-payers remaining in financial distress one year ahead as opposed to $68.76 \%$ of underpayers. Moreover, over-payers that are not financially distressed are more likely to become financially distressed one year later (3.66\%) compared to under-payers $(2.47 \%)$.

We further assess the relation between the financial distress spectrum and over- / underpayment by classifying over-payers and under-payers in quintiles of Default probability (Panel B, Table 7). The results confirm our previous findings showing that over-payers that are on the lowest default probability quintile (quintile 1) have a $2.90 \%$ likelihood of moving to the highest financial distress quintile (quintile 5) compared to $1.70 \%$ for under-payers. Moreover, overpayers that are on the third quintile of financial distress are more likely $(16.55 \%)$ to move to the highest quintile of financial distress compared to under-payers (10.25\%). Panel C reports the results on the transition probabilities based on Default probability (CHS) and shows that even though under-payers and over-payers that are placed in the middle of the financial distress spectrum have a similar likelihood of remaining one year ahead in the same position in the spectrum (30.86\% and 30.67\% respectively), over-payers have a higher probability of becoming more financially distressed (27.62\% and $12.34 \%$ for quintiles 4 and 5) compared to under-payers

\footnotetext{
${ }^{16}$ For the sake of brevity, in Tables 7 and 8 we only tabulate the results for Z-score - Dummy, Default probability, and Default probability $(\mathrm{CHS})$. We repeat our analysis on transition probabilities for Interest coverage, Zmijewskiscore, and $O$-score and the results remain qualitatively the same.
} 
(22.46\% and $7.7 \%$ for quintiles 4 and 5). We also find that over-payers that are on the highest default probability quintile are $63.32 \%$ more likely to remain financially distressed one year ahead compared to $49.48 \%$ of under-payers. Overall, these results suggest that firms that overpay are more likely to become riskier and score higher on the financial distress spectrum compared to under-payers. This is in line with the Reduced-flexibility hypothesis and supports our earlier findings on the relation between overpayment and higher risk.

\section{[Insert Table 7 about here]}

Since our earlier findings show there is a higher likelihood of an increase in financial distress following an overpayment, we further assess whether the reverse also applies, i.e., whether there is a higher likelihood of overpayment following an increase in financial distress. The results in Panel A, Table 8, show there is a difference in the overpaying dynamics between firms that are financially distressed $(Z$-score - Dummy $=0)$ and those that are financially healthy $(Z$-score - Dummy=1). $67.78 \%$ of over-payers continue to overpay a year later when they are currently financially distressed, compared to $64.37 \%$ of over-payers that are financially healthy. Similarly, under-payers are more likely to become over-payers one year later if they are currently distressed (a probability of $30.17 \%$ against $24.63 \%$ ). The results for Default probability (Panel B) show that there are no significant differences in the transition probabilities for over-payers between quintiles 1 and 5 of this variable. In contrast, $36 \%$ of under-payers that are currently in distress (quintile 5) become over-payers in the next period, against a probability of only $22 \%$ for quintile 1. The differences are more marked for Default probability (CHS). The results in Panel C show that overpaying firms with a high probability of default have a $68.57 \%$ likelihood of continuing to overpay one year ahead, as opposed to a probability of only $58.84 \%$ for overpayers with a low probability of default. Differences in transition probabilities are even larger for 
under-payers. In line with the Risk-shifting hypothesis, our results show that firms that are more financially distressed are more likely to continue, or to start, overpaying. Overall, our findings show that distressed firms are more likely to overpay but also that over-payers are more likely to become financially distressed.

\section{[Insert Table 8 about here]}

\section{Future firm growth and changes in risk}

If over-payers' actions are affected by distress and risk-shifting incentives, then we would expect them to behave in a consistent manner also in relation to other financial policies. Favara et al.'s (2017) theoretical model shows that distressed firms have incentives to engage in riskshifting through asset substitution (Jensen and Meckling, 1976), which boosts firm risk, and to under-invest (Myers, 1977). In light of this model, in Table 9, we analyze future changes in assets, sales, PPE, and several risk measures, capturing both equity and assets risk, for nonpayers, under-payers, and over-payers over a five-year period. Focusing on the comparison between under- and over-payers, we find that over-payers experience significantly smaller future changes in assets, sales, and PPE. At the same time, variations in risk are generally smaller for under-payers even though the differences between the two types of payers are not always statistically significant. This evidence is in line with Favara et al.'s (2017) theoretical predictions and further confirms our conjecture that over-payers tend to engage in risk-shifting.

[Insert Table 9 about here] 


\section{Determinants of overpaying}

\subsection{The role of institutional investors}

Risk-shifting through excessive payouts could be beneficial to shareholders but also detrimental to managers (e.g., Hernandez-Lagos et al., 2017); thus, we expect a positive relation between the presence of powerful shareholders with strong risk-shifting incentives and overpayment. Institutional investors can influence firms' payout decisions through monitoring (Crane et al., 2016; Harford et al., 2017); this is particularly true for those investors with longterm investment horizons (Aghion et al., 2013; Harford et al., 2017), who tend to hold diversified portfolios (Bushee, 1998; 2001). Therefore, we assess whether institutional investors, and in particular heterogeneity in their investment horizons, are associated with firm overpayment.

We employ a standard logit model where the dependent variable is a binary variable that equals one if a firm is an over-payer and zero for under-payers based on the Mid-point classification method discussed earlier. Table 10 provides an overview of the financial distress and the institutional ownership variables for firm-years with positive payouts (under-payers and over-payers) that we consider in our logit models. Compared to the overall sample of observations (see Table 1), the sub-sample reported in Table 10 shows lower levels of financial distress, of the likelihood of liquidation and/or being dropped from a stock exchange, and of the probability of a bankruptcy event. This is expected since this sub-sample only contains payers. In this sub-sample, institutional investors hold approximately $41 \%$ of firms' shares and their average portfolio turnover is approximately 0.19 . Moreover, long-term investors hold approximately $8 \%$ with quasi-indexers having significantly higher holdings of approximately $27 \%$.

[Insert Table 10 about here] 
As in Harford et al. (2017) and in line with their reasoning, in all our multivariate models we control for total Institutional ownership. We need to include this control variable since a firm's ownership structure may affect its payout policy. Moreover, ownership by all types of institutional investors is probably correlated with ownership by long-term investors since some firms are inherently more attractive to institutional investors than others. Thus, we can isolate the effect of long-term institutions only if we control for total ownership by institutions.

The results from the logit regression, provided in Table 11 column (1), show that total Institutional ownership is negatively related to the likelihood of a firm becoming an over-payer. For instance, a one standard deviation increase in institutional investors' shareholdings is associated with a reduction in the likelihood of overpaying by approximately $6 \%$. However, after controlling for total institutional ownership, we find that a one standard deviation decrease in Investor turnover, i.e., an increase in the investment horizon of the average institutional shareholder in the firm, is associated with an increase in the likelihood of overpaying by approximately $2.2 \%$ (column (2)). This result is confirmed by column (3), where we find that a one standard deviation increase in ownership by long-term investors (Low turnover institutional ownership) is associated with an increase in the likelihood of overpaying by approximately 2.6\%. These results suggest that the presence of long-term investors is positively correlated with the likelihood of a firm becoming an over-payer. One explanation is that long-term investors influence firms to increase their payouts to excessive levels, which in turn increases firms' financial distress (the Reduced-flexibility hypothesis). Alternatively, long-term investors, knowing that some firms they invest in have higher financial distress risk, influence their payout decisions in order to transfer wealth from debtholders to shareholders (the Risk-shifting hypothesis). However, a positive relation between the likelihood of being an over-payer and the 
presence of long-term investors may also be driven by self-selection since long-term investors may simply prefer over-payers. We attempt to control for self-selection by focusing on quasiindexer institutional investors as in Harford et al. (2017). Since quasi-indexer investors track an index, they neither shift their portfolios often nor do they actively choose the firms they invest in since they have to replicate the index. Therefore, they are not active investors but can have a significant influence on firms' decision making, as shown by Appel et al. (2016). Similarly to Crane et al. (2016), we rely on the investor definitions created by Bushee (2001) for this analysis.

The results reported in Table 11 (column (4)) show that ownership, by both dedicated and quasi-indexer institutional investors, has a positive relation with overpayment. A one standard deviation increase in ownership held by dedicated and quasi-indexer institutions is associated with an increase in the likelihood of overpaying by approximately $2.5 \%$ and $8.5 \%$ respectively. The results are consistent with long-term investors influencing firms into overpaying. Our findings are in line with Harford et al. (2017) who find that investors with longer investor horizons push firms to increase their payouts to shareholders and with Appel et al. (2016) who show that passive investors have a "strong voice" and can exert influence over important corporate decisions. Importantly, these findings indicate that our main results ${ }^{17}$ are not driven by self-selection stemming from the investment decisions of institutional investors.

\footnotetext{
17 A firm's dividend policy is also influenced by its peers (Popadak, 2014), its investors' time varying demands (Baker and Wurgler, 2004; Kulchania, 2013), its geographic location (John et al., 2011) and local shareholder clientele (Becker et al., 2011), while neighboring firms can significantly influence firms' financial policy decision making (Gao et al., 2011). Therefore, in untabulated results we also control for the influence of catering to investors (Dividend premium and alternatively Share Repurchase premium), peer firms (Industry propensity to overpay), and
} 


\section{[Insert Table 11 about here]}

\subsection{The role of financial distress}

Based on the Risk-shifting hypothesis, firms are incentivized to engage in large payouts and transfer wealth from debtholders to shareholders when they are financially distressed. Financial distress can, therefore, be a determinant of the likelihood to overpay. We re-estimate the logit models of Table 11, adding our financial distress variables, one at a time, as additional determinants. For the sake of brevity, we only tabulate the findings for Default Probability in Table 12, but the results for the other distress measures are qualitatively similar. In Panel A, we assume that financial distress is an exogenous determinant of overpaying and report a positive and highly statistically significant coefficient on Default probability, suggesting that higher distress is associated with a firm's propensity to overpay. Importantly, after controlling for financial distress, we confirm our primary results for the institutional ownership variables.

The estimates in Panel A can be affected by reverse causality bias since a firm can become more financially distressed through particularly large payouts (the Reduced flexibility hypothesis), so financial distress could be endogenous. In Table 12 Panel B, we re-estimate the multivariate models of Panel A, this time relying on an instrumental variable (IV) probit method in which Default probability is assumed to be endogenous. We instrument firm-specific financial distress by using Industry average distress, which is the average level of distress based on the probability of default for firm-years from the same period and belonging to the firm's industry based on the Fama-French 49 industry classification, excluding the firm under consideration.

\footnotetext{
location (Industry propensity to overpay) on the propensity to overpay. After controlling for these alternative explanations our results on the institutional ownership variables remain qualitatively similar and significant (both statistically and economically).
} 
First-stage regression estimates (column (1) - results are similar for other untabulated first-stage models) show that there is a positive and statistically strong relation between Default probability and its instrument.

Given the recent criticism by Gormley and Matsa (2014) about using the industry average of the dependent variable as an instrument, we alternatively use as an instrument the industrywide economic distress (Industry economic distress). In the spirit of Acharya et al. (2007), we classify a firm as being distressed when the industry's median stock return is equal to or lower than $-30 \%$, based on the Fama-French 49 industries. The rationale for using this measure as an instrument is that when the assets of a firm are specific to an industry, hence, not available to be redeployed on another industry, this firm will experience lower liquidation value in case of a fire-sale, especially when other firms in the same industry are also in distress (Acharya et al., 2007). We expect industry-wide economic distress to have an impact on the financial distress risk of a firm that is part of that industry. The first-stage regression estimates on the Industry economic distress (column (1) - results are similar for other untabulated first-stage models) reported in Panel C show a positive and statistically significant relation between Default probability and its instrument, similarly to our previous findings in Panel B. While we cannot directly test the exclusion restriction, it is implausible that the average level of financial distress within a particularly industry or the industry-wide economic distress should directly influence a firm's propensity to overpay after controlling for a wide array of determinants, including firmspecific distress. It is worth noting that the p-values of the Wald exogeneity tests reported in Panels B and C are very small, supporting the notion that financial distress is endogenous. Overall, the empirical findings in Panels B and C are qualitatively similar to those in Panel A. 
After controlling for the positive impact of distress on overpayment, we still find that holdings by long-term institutional investors are associated with overpayment.

\section{[Insert Table 12 about here]}

\section{Conclusion}

Despite the increasing attention of practitioners and commentators on large corporate payouts and the continuous pressure that managers face to distribute their significant cash holdings, there is limited evidence on the potential costs of excessive levels of payouts. We study a large sample of non-financial publicly-listed US firms and use a set of commonly accepted variables to identify firms that pay out more (less) than expected, which we label as over-payers (under-payers). Using a comprehensive set of accounting- and market-based financial distress variables and firm survival measures, we find that, compared to under-payers, over-payers are higher on the financial distress spectrum and are more likely to involuntarily delist and be involved in a bankruptcy case. Through a transition probability analysis, we show that the relation between the likelihood of overpaying and financial distress runs in both directions.

Since there is evidence suggesting that investors can influence firms' payout policy, we test whether institutional investors' ownership can be a channel that explains the firm overpaying behavior, even though such payout policies are linked to higher distress and shorter lifespan. Consistent with theoretical predictions relating to risk-shifting, we find that the ownership by long-term investors, who are likely to be well-diversified and effective monitors, is higher in firms that overpay. We confirm this finding by showing that quasi-indexer institutional ownership is also positively and significantly related to the likelihood of a firm overpaying, which mitigates concerns over self-selection driving our findings. Given that it is hard to make a strong claim over a causal effect of long-term institutional investment on overpayment, 
throughout this paper we avoid doing so. However, collectively our results point toward a role of long-term institutional investors in excess corporate payouts.

Overall, in this study we report a positive association between overpayment and financial distress, which, according to our findings, is likely to be affected by the risk-shifting incentives of long-term institutional investors. 


\section{Appendix. Variable Definitions}

This appendix presents detailed definitions for all the variables used in the study.

\begin{tabular}{ll}
\hline Payout variables & Definitions \\
\hline Repurchases & Common dividends (Compustat item DVC) over Market capitalization. \\
& Purchase of common and preferred stock (Compustat item PRSTKC) \\
& minus the reduction in the book value of preferred stock (Compustat \\
& item PSTKRV), all scaled by Market capitalization. \\
Total payout & Sum of Dividends and Repurchases. \\
\hline Payout determinants & Definitions \\
\hline Book equity & Book equity is stockholders' equity (Compustat item SEQ) or book \\
& common equity (Compustat item CEQ) plus book preferred stock \\
& total liabilities (Compustat item LT), minus Preferred stock, plus \\
& deferred taxes and investment tax credit (Compustat item TXDITC), if \\
& available, minus the postretirement benefit asset (Compustat item \\
PRBA), if available.
\end{tabular}

Cash flow

Operating income before depreciation (Compustat item OIBDP) over total assets (Compustat item AT).

Cash holdings

Cash and short-term investments (Compustat item CHE) over total assets (Compustat item AT).

Firm age

Years since the firm's first appearance in CRSP.

Firm market value Total assets (Compustat item AT) minus Book equity plus Market capitalization.

Firm size Natural $\log$ of inflation-adjusted Market capitalization (using the consumer price index CPIAUCSL from FRED). 
Idiosyncratic risk

Leverage

Market capitalization

Market-to-book

Preferred stock

Retained earnings

Systematic risk
Standard deviation of the residuals from a regression of the daily stock return (source: CRSP) in excess of the risk free rate (from Kenneth French's website) on the market factor based on the value-weighted market return (source: CRSP). Daily returns over the fiscal year are used.

Long-term debt (Compustat item DLTT) plus long-term debt due in one year (Compustat item DD1) over Firm market value.

Market capitalization at the end of the fiscal year (Compustat item PRCC times item CSHO).

Firm market value over total assets (Compustat item AT).

Preferred stock is the liquidating value of preferred stock (Compustat item PSTKL) or the redemption value of preferred stock (Compustat item PSTKRV) or the par value of preferred stock (Compustat item PSTK). If items PSTKL, PSTKRV, and PSTV are not available, preferred stock is set to zero.

Retained earnings (Compustat item RE) over total assets (Compustat item AT).

Standard deviation of the predicted value from a regression of the daily stock return (source: CRSP) in excess of the risk free rate (from Kenneth French's website) on the market factor based on the valueweighted market return (source: CRSP). Daily returns over the fiscal year are used. 


\begin{tabular}{|c|c|}
\hline $\begin{array}{l}\text { Financial distress } \\
\text { variables }\end{array}$ & Definitions \\
\hline Change in net income & $\begin{array}{l}\text { Change in net income (Compustat item NI) over the sum of the } \\
\text { absolute values of the current and lagged net income. }\end{array}$ \\
\hline CHS-score & $\begin{array}{l}\text { Score computed using the coefficients from Column } 4 \text { in Table IV of } \\
\text { Campbell et al. (2008). }\end{array}$ \\
\hline Default probability & $\mathrm{N}(-$ Distance to default $) * 100$ \\
\hline Default probability $(\mathrm{CHS})$ & $(1 /(1+\exp (-$ CHS-score $))) * 100$. \\
\hline Distance to default & $\begin{array}{l}\text { Bharath and Shumway's (2008) Merton's (1974) distance to default } \\
\text { naïve measure. }\end{array}$ \\
\hline Dummy losses & $\begin{array}{l}\text { Binary variable that equals one if the sum of the current and lagged net } \\
\text { income (Compustat item NI) is negative. Otherwise, it equals zero. }\end{array}$ \\
\hline Funds from operations & $\begin{array}{l}\text { Total funds from operations (Compustat item FOPT) or cash flow from } \\
\text { operating activities (Compustat item OANCF) minus increase in } \\
\text { accounts payable and accrued liabilities (Compustat item APALCH) } \\
\text { minus decrease in inventory (Compustat item INVCH) minus decrease } \\
\text { in accounts receivable (Compustat item RECCH) minus increase in } \\
\text { accrued income taxes (Compustat item TXACH) minus net increase in } \\
\text { other liabilities (Compustat item AOLOCH). }\end{array}$ \\
\hline Interest coverage & $\begin{array}{l}\text { Natural log of one plus the sum of interest expenses (Compustat item } \\
\text { XINT) and operating income after depreciation (Compustat item } \\
\text { OIADP) over interest expenses. The variable is set to missing if } \\
\text { operating income after depreciation is not positive. }\end{array}$ \\
\hline Negative equity dummy & $\begin{array}{l}\text { Binary variable that equals one if total liabilities (Compustat item LT) } \\
\text { are larger than total assets (Compustat item AT). Otherwise, it equals } \\
\text { zero. }\end{array}$ \\
\hline
\end{tabular}


O-score

Zmijewski-score

Z-score - Dummy
Ohlson's (1980) O-score is computed as follows:

O-score $=-1.32-0.407 * \log (($ item AT $* 1,000,000) /$ GNP price-level index $)+6.03 *($ item LT / item AT $)-1.43 *(($ item ACT - item LCT $) /$ item AT) $+0.076 *$ (item LCT / item ACT) $-1.72 *$ Negative equity dummy $-2.37 *$ (item NI / item AT) $-1.83 *$ (Funds from operations / item LT) $+0.285 *$ Dummy losses $-0.521 *$ Change in net income. All items are from Compustat. The GNP price-level index is from FRED and is set to 100 for the year 1968 .

Zmijewski's (1984) score is computed as follows:

Zmijewski-score $=-4.336-4.513 *($ item NI $/$ item AT $)+5.679 *($ item $\mathrm{LT} /$ item AT) $+0.004 *$ (item ACT / item LCT). All items are from Compustat.

A binary variable that equals one if Altman's (1968) Z-score is higher than 1.81 and zero otherwise. The Z-score is computed as follows:

Z-score $=3.3 *($ item OIADP / item AT $)+1.2 *(($ item ACT - item $\mathrm{LCT}) /$ item AT) + item SALE / item AT + $0.6 *(($ item CSHO * item PRCC) / (item DLTT + item DLC) $)+1.4 *($ item RE / item AT). All items are from Compustat.

\footnotetext{
Firm survival variables

Bankruptcy (year+5)

Exchange dropped

(year+5)

\section{Definitions}

Binary variable that equals one if the firm is subject to a Chapter 7 or Chapter 11 bankruptcy case (source: Thomson SDC Platinum and http://lopucki.law.ucla.edu) in the subsequent five years. Otherwise, it equals zero.

Binary variable that equals one if the stock is delisted due to being dropped from the exchange (source: CRSP delisting codes 500-591) in
} 
the subsequent five years. Otherwise, it equals zero.

Exchange transaction (year+5)

Liquidation (year+5)

Liquidation and Exchange dropped (year+5)

Merger and acquisition $($ year+5)
Binary variable that equals one if the stock is delisted due to an exchange transaction (source: CRSP delisting codes 300-390) in the subsequent five years. Otherwise, it equals zero.

Binary variable that equals one if the stock is delisted due to a liquidation (source: CRSP delisting codes 400-490) in the subsequent five years. Otherwise, it equals zero.

Binary variable that equals one if the stock is delisted due to being liquidated or dropped from the exchange (source: CRSP delisting codes $400-490$ or 500-591) in the subsequent five years. Otherwise, it equals zero.

Binary variable that equals one if the stock is delisted due to a merger (source: CRSP delisting codes 200-290) in the subsequent five years. Otherwise, it equals zero.

\section{Institutional ownership Definitions variables \\ High turnover institutional Ownership of high turnover institutional investors defined as in Gaspar ownership \\ et al. (2012) (source: Thomson Reuters Institutional Holdings database). \\ Institutional ownership Fraction of common shares outstanding held by institutional investors (source: Thomson Reuters Institutional Holdings database). \\ Investor turnover Gaspar et al.'s (2012) investor turnover measure (source: Thomson Reuters Institutional Holdings database). \\ Low turnover institutional ownership \\ Ownership of low turnover institutional investors defined as in Gaspar et al. (2012) (source: Thomson Reuters Institutional Holdings}


database).

Mid turnover institutional ownership

\section{Ownership of dedicated} institutions Ownership of quasi-indexer
institutions

Ownership of transient institutions

Other variables

City propensity to overpay overpay

Industry average distress

Industry economic distress

$\Delta$ Idiosyncratic risk
Ownership of mid turnover institutional investors defined as in Gaspar et al. (2012) (source: Thomson Reuters Institutional Holdings database).

Ownership of dedicated institutions (sources: classifications from Brian Bushee's website; Thomson Reuters Institutional Holdings database).

Ownership of quasi-indexer institutions (sources: classifications from Brian Bushee's website; Thomson Reuters Institutional Holdings database).

Ownership of transient institutions (sources: classifications from Brian Bushee's website; Thomson Reuters Institutional Holdings database).

\section{Definitions}

The annual average value of the over-payer binary variable for firmyear observations from firms headquartered in the same city (based on data from Compustat), excluding the firm under consideration.

The annual average value of the over-payer binary variable for firmyear observations from the same industry based on Fama-French 49 industries, excluding the firm under consideration.

The annual average value of Default probability for firm-year observations from the same industry based on Fama-French 49 industries, excluding the firm under consideration.

A binary variable that takes the value of one if an industry's median stock return is equal to or lower than $-30 \%$ and zero otherwise, based on Fama-French 49 industries.

Percentage change in Idiosyncratic risk. 
$\triangle P P E$

$\triangle$ Sales

$\triangle$ Sigma assets

$\triangle$ Sigma equity

Systematic risk

$\triangle$ Total assets
Percentage change in plant, property, and equipment (Compustat item PPENT).

Percentage change in sales (Compustat item SALE).

Percentage change in asset volatility defined as in Bharath and Shumway's (2008) naïve model.

Percentage change in the standard deviation of monthly returns (source:

CRSP) over the fiscal year.

Percentage change in Systematic risk.

Percentage change in total assets (Compustat item AT). 


\section{References}

Acemoglu, D., Zilibotti, F., 1997. Was Prometheus unbound by chance? Risk, diversification, and growth. Journal of Political Economy 105, 709-751.

Acharya, V.V., Le, H., Shin, H.S., 2017. Bank capital and dividend externalities. Review of Financial Studies 30, 988-1018.

Acharya, V.V., Bharath, S.T., Srinivasan, A., 2007. Does industry-wide distress affect defaulted firms? Evidence from creditor recoveries. Journal of Financial Economics 85, 797-821.

Aghion, P., Van Reenen, J., Zingales, L., 2013. Innovation and institutional ownership. American Economic Review 103, 277-304.

Altman, E.I., 1968. Financial ratios, discriminant analysis and the prediction of corporate bankruptcy. Journal of Finance 23, 589-609.

Anantharaman, D., Lee, Y.G., 2014. Managerial risk taking incentives and corporate pension policy. Journal of Financial Economics 111, 328-351.

Appel, I.R., Gormley, T.A., Keim, D.B., 2016. Passive investors, not passive owners. Journal of Financial Economics 121, 111-141.

Baesel, J.B., 1974. On the assessment of risk: some further considerations. Journal of Finance $29,1491-1494$.

Baker, M., Wurgler, J., 2004. A catering theory of dividends. Journal of Finance 59, 1125-1165.

Becker, B., Ivković, Z., Weisbenner, S., 2011. Local dividend clienteles. Journal of Finance 66, $655-683$.

Becker, S., Caliendo, M., 2007. Sensitivity analysis for average treatment effects. Stata Journal $7,71-83$. 
Bharath, S.T., Shumway, T., 2008. Forecasting default with the Merton distance to default. Review of Financial Studies 21, 1339-1369.

Bhattacharya, U., Borisov, A., Yu, X., 2015. Firm mortality and natal financial care. Journal of Financial and Quantitative Analysis 50, 61-88.

Black, F., 1976. The dividend puzzle. Journal of Portfolio Management 2, 5-8.

Bonaimé, A.A., Hankins, K.W., Harford, J., 2014. Financial flexibility, risk management, and payout choice. Review of Financial Studies 27, 1074-1101.

Brockman, P., Martin, X., Unlu, E., 2010. Executive compensation and the maturity structure of corporate debt. Journal of Finance 65, 1123-1161.

Bushee, B.J., 1998. The influence of institutional investors on myopic R\&D investment behavior. Accounting Review 73, 305-33.

Bushee, B.J., 2001. Do institutional investors prefer near-term earnings over long-run value? Contemporary Accounting Research 18, 207-246.

Campbell, J.Y., Hilscher, J., Szilagyi, J., 2008. In search of distress risk. Journal of Finance 63, 2899-2939.

Cella, C. 2014. Institutional investors and corporate investment. Stockholm School of Economics. Unpublished working paper.

Chava, S., Purnanandam, A., 2010. Is default risk negatively related to stock returns? Review of Financial Studies 23, 2523-2559.

Chen, S.-S., Wang, Y., 2012. Financial constraints and share repurchases. Journal of Financial Economics 105, 311-331.

Conrad, J., Kapadia, N., Xing, Y., 2014. Death and jackpot: Why do individual investors hold overpriced stocks? Journal of Financial Economics 113, 455-475. 
Crane, A.D., Michenaud, S., Weston, J.P., 2016. The effects of institutional ownership on payout policy: evidence from index thresholds. Review of Financial Studies 29, 1377-1408.

Cremers K.J.M., Petajisto, A., 2009. How active is your fund manager? A new measure that predicts performance. Review of Financial Studies 22, 3329-3365.

Davydenko, S.A., Strebulaev, I.A., 2007. Strategic actions and credit spreads: an empirical investigation. Journal of Finance 62, 2633-2671.

DeAngelo, H., DeAngelo, L., Stulz, R.M., 2006. Dividend policy and the earned/contributed capital mix: a test of the life-cycle theory. Journal of Financial Economics 81, 227-254.

DeMarzo, P.M., Fishman, M.J., 2007. Optimal long-term financial contracting. Review of Financial Studies 20, 2079-2128.

Derrien, F., Kecskés, A., Thesmar, D., 2013. Investor horizons and corporate policies. Journal of Financial and Quantitative Analysis 48, 1755-1780.

Desai, M.A., Jin, L., 2011. Institutional tax clienteles and payout policy. Journal of Financial Economics 100, 68-84.

Dhillon, U.S., Johnson, H., 1994. The effect of dividend changes on stock and bond prices. Journal of Finance 49, 291-289.

Dittmar, A.K., 2000. Why do firms repurchase stock? Journal of Business 73, 331-355.

Eisdorfer, A., 2008. Empirical evidence of risk shifting in financially distressed firms. Journal of Finance 63, 609-637.

von Eije, H., Goyal, A., Muckley, C.B., 2014. Does the information content of payout initiations and omissions influence firm risks? Journal of Econometrics 183, 222-229.

Fama, E.F., French, K.R., 2001. Disappearing dividends: changing firm characteristics or lower propensity to pay? Journal of Financial Economics 60, 31-43. 
Fan, H., Sundaresan, S.M., 2000. Debt valuation, renegotiation, and optimal dividend policy. Review of Financial Studies 13, 1057-1099.

Favara, G., Schroth, E., Valta, P., 2012. Strategic default and equity risk across countries. Journal of Finance 67, 2051-2095.

Favara, G., Morellec, E, Schroth, E., Valta, P., 2017. Debt enforcement, investment, and risk taking across countries. Journal of Financial Economics 123, 22-41.

Galai, D., Masulis, R.W., 1976. The option pricing model and the risk factor of stock. Journal of Financial Economics 3, 53-81.

Gangl, M., 2004. Rbounds: Stata module to perform Rosenbaum sensitivity analysis for average treatment effects on the treated. Available from: http://ideas.repec.org/c/boc/bocode/s438301.html

Gao, W., Ng, L., Wang, Q., 2011. Does corporate headquarters location matter for corporate financial policies? Financial Management 40, 113-138.

Garlappi, L., Shu, T., Yan, H., 2008. Default risk, shareholder advantage, and stock returns. Review of Financial Studies 21, 2743-2778.

Garlappi, L., Yan, H., 2011. Financial distress and the cross-section of equity returns. Journal of Finance 66, 789-822.

Gaspar, J-M., Massa, M., Matos, P., 2005. Shareholder investment horizons and the market for corporate control. Journal of Financial Economics 76, 135-165.

Gaspar, J-M., Massa, M., Matos, P., Patgiri, R., Rehman, Z., 2012. Payout policy choices and shareholder investment horizons. Review of Finance 17, 261-320.

Gilje, E.P., 2016. Do firms engage in risk-shifting? Empirical evidence. Review of Financial Studies 29, 2925-2954. 
Gormley, T., Matsa, D., 2014. Common errors: How to (and not to) control for unobserved heterogeneity. Review of Financial Studies 27, 617-661.

Grinstein, Y., Michaely, R., 2005. Institutional holdings and payout policy. Journal of Finance 60, 1389-1426.

Grullon, G., Michaely, R., 2002. Dividends, share repurchases, and the substitution hypothesis. Journal of Finance 57, 1649-1684.

Grullon, G., Michaely, R., 2004. The information content of share repurchase programs. Journal of Finance 59, 651-680.

Grullon, G., Michaely, R., Swaminathan, B., 2002. Are dividend changes a sign of firm maturity? Journal of Business 75, 387-424.

Harford, J., Kecskés, A., Mansi, S., 2017. Do long-term investors improve corporate decision making? Unpublished working paper. Available at SSRN: http://ssrn.com/abstract=2505261.

Hernandez-Lagos, P., Povel, P., Sertsios, G., 2017. An experimental analysis of risk-shifting behavior. Review of Corporate Finance Studies 6, 68-101.

Hoberg, G., Prabhala, N.R., 2009. Disappearing dividends, catering, and risk. Review of Financial Studies 22, 79-116.

Jagannathan, M., Stephens, C.P., Weisbach, M.S., 2000. Financial flexibility and the choice between dividends and stock repurchases. Journal of Financial Economics 57, 355-384.

Jensen, M.C., Meckling, W.H., 1976. Theory of the firm: managerial behavior, agency costs and ownership structure. Journal of Financial Economics 3, 305-360.

John, K., Knyazeva, A., Knyazeva, D., 2011. Does geography matter? Firm location and corporate payout policy. Journal of Financial Economics 101, 533-551. 
Kulchania, M., 2013. Catering driven substitution in corporate payouts. Journal of Corporate Finance 21, 180-195.

Lambrecht, B.M., Myers S.C., 2012. A Lintner model of payout and managerial rents. Journal of Finance 67, 1761-1810.

Leary, M.T., Michaely, R. 2011. Determinants of dividend smoothing: empirical evidence. Review of Financial Studies 21, 3197-3249.

Mansi, S.A., Maxwell, W.F., Wald, J.K., 2009. Creditor protection laws and the cost of debt. Journal of Law \& Economics 52, 701-717.

Maxwell, W., Stephens, C., 2003. The wealth effects of repurchases on bondholders. Journal of Finance 58, 895-919.

Merton, R.C., 1974. On the pricing of corporate debt: the risk structure of interest rates. Journal of Finance 29, 449-70.

Michaely, R., Qian, M., 2017. Stock liquidity and dividend policy: dividend policy changes following an exogenous liquidity shock. Unpublished working paper. Available at SSRN: https://ssrn.com/abstract=2894164.

Myers, S.C., 1977. Determinants of corporate borrowing. Journal of Financial Economics 5, 147175.

Ohlson, J.A., 1980. Financial ratios and the probabilistic prediction of bankruptcy. Journal of Accounting Research 18, 109-131.

Opler, T., Pinkowitz, L., Stulz, R., Williamson, R., 1999. The determinants and implications of corporate cash holdings. Journal of Financial Economics 52, 3-46. 
Platt, E., MacKenzie, M., 2015. US companies on course to return $\$ 1$ tn to shareholders, Financial Times, April 12, Available at: http://www.ft.com/cms/s/0/2c1a34d8dfa511e4a06a00144feab7de.html\#axzz3X634h4Bf.

Popadak, J., 2014. Dividend payments as a response to peer influence, Duke University Unpublished working paper.

Pryschepa, O., Aretz, K., Banerjee, S., 2013. Can investors restrict managerial behavior in distressed firms? Journal of Corporate Finance 23, 222-239.

Rosenbaum P.R., 2002. Attributing Effects to Treatment in Matched Observational Studies, Journal of the American Statistical Association 97, 183-192.

Rosenbaum P.R., 2005. Heterogeneity and causality: unit heterogeneity and design sensitivity in observational studies. American Statistician 59, 147-152.

Rosenbaum P.R., 2010. Design of Observational Studies. Springer Series in Statistics.

Rozeff, M.S., 1982. Growth, beta and agency costs as determinants of dividend payout ratios. Journal of Financial Research 5, 249-259.

Salmon, F., 2012. The problem with buybacks, Dell edition, Reuters, September 4, Available at: http://blogs.reuters.com/felix-salmon/2012/09/04/the-problem-with-buybacks-dell-edition/.

Smith, C.W., Warner, J.B., 1979. On financial contracting. An analysis of bond covenants. Journal of Financial Economics 7, 117-161.

Udland, M., 2016. The amount of cash corporate America is dishing to investors sends a scary signal about the stock market's future, Business Insider, July 1, Available at: http://uk.businessinsider.com/total-stock-market-payout-near-a-record-high-2016-7.

Zmijewski, M.E., 1984. Methodological issues related to the estimation of financial distress prediction models. Journal of Accounting Research 22, 59-82. 


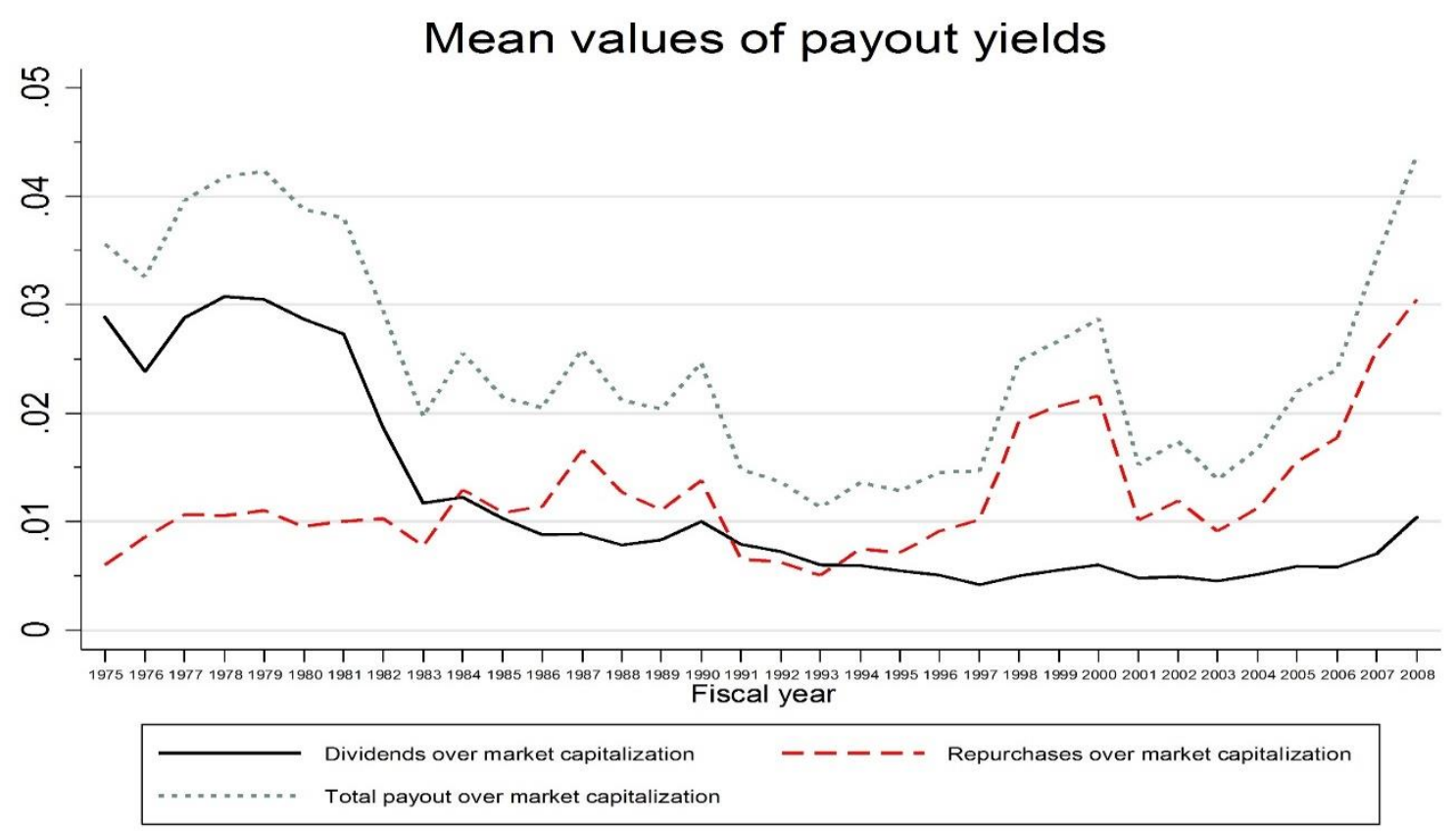

Figure 1. Payout yields over time. The graph shows the average annual dividend, share repurchase, and total payout yields of US listed firms in our sample from 1975 to 2008. All variables are defined in the Appendix.

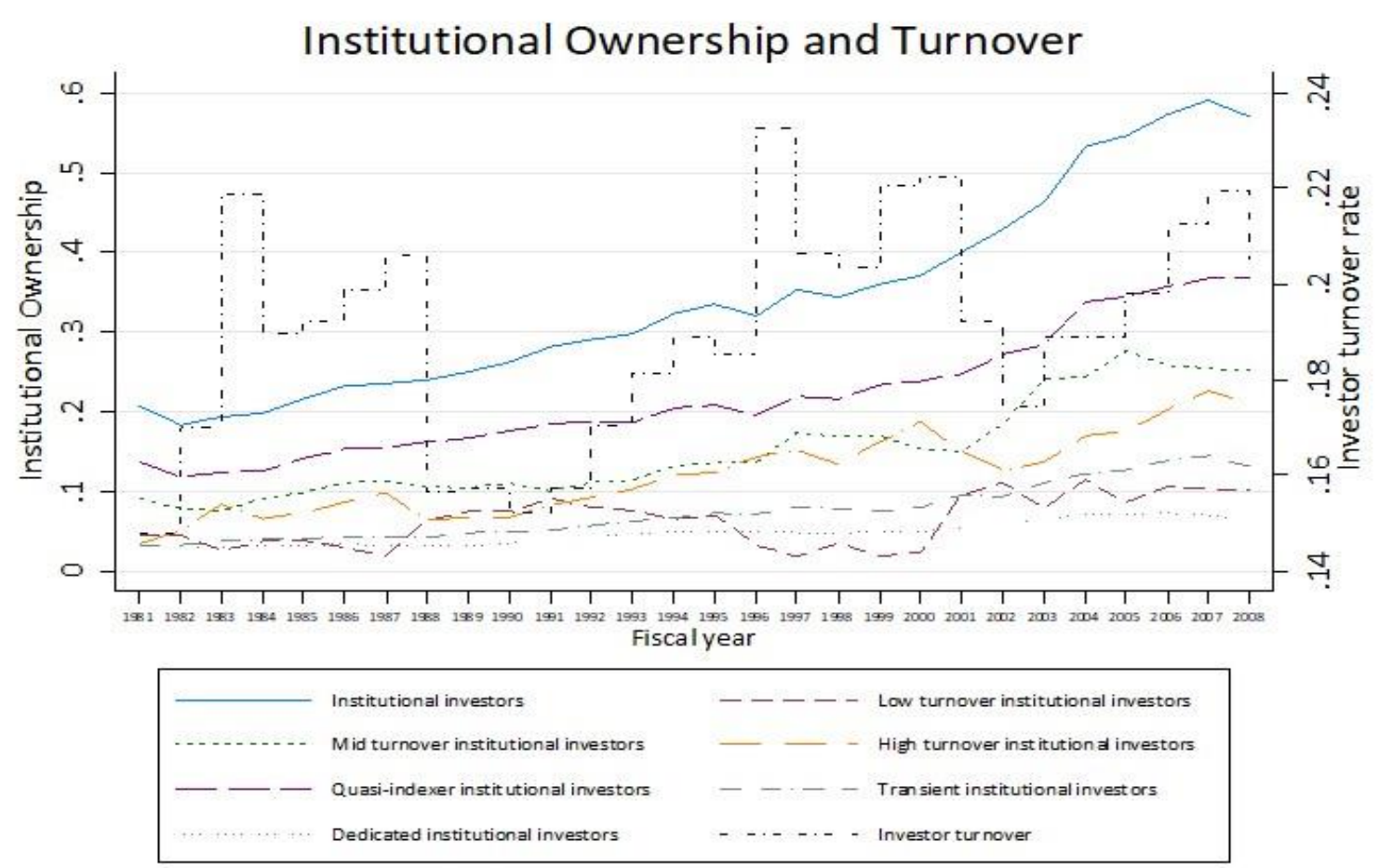

Figure 2. Institutional ownership and investor turnover over time. The graph is based on the annual shareholdings of institutional investors from 1981 to 2008. All variables are defined in the Appendix. 


\section{Table 1. Summary Statistics}

This table presents summary statistics for the sample used in this study covering the period 1975-2008 in Panels A and B (1980-2008 for the bankruptcy variable) and the period 1981-2008 in Panel C. We exclude financial firms (SIC codes 6000-6999), utilities (SIC codes 4900-4949), and securities other than common stock. Panel A reports the total payout (measured as the sum of dividends and share repurchases) scaled by market capitalization and the variables used for identifying the expected payout estimated in Table 2. Panel B reports an array of alternative financial distress and firm survival (voluntary and involuntary delisting and bankruptcy filing) measures. Survival measures are computed over the five years following the current period $(\mathrm{t})$. Panel $\mathrm{C}$ reports the institutional ownership variables. All nonbinary variables, are winsorized at the $1 \%$ and $99 \%$ tails. All the variables are defined in the Appendix.

\begin{tabular}{lcccccc}
\hline \multicolumn{1}{l}{ Panel A. Total Payout and Payout Controls } \\
& $N$ & Mean & Median & St. Dev. & Min & Max \\
Total payout & 76,392 & 0.023 & 0.002 & 0.042 & 0.000 & 0.260 \\
Cash flow & 76,392 & 0.079 & 0.118 & 0.190 & -0.907 & 0.366 \\
Market-to-book & 76,392 & 1.709 & 1.291 & 1.293 & 0.582 & 8.679 \\
Firm size & 76,392 & 4.280 & 4.122 & 2.097 & 0.022 & 9.644 \\
Leverage & 76,392 & 0.180 & 0.137 & 0.167 & 0.000 & 0.688 \\
Retained earnings & 76,392 & -0.116 & 0.163 & 1.049 & -6.328 & 0.782 \\
Cash holdings & 76,392 & 0.123 & 0.059 & 0.157 & 0.000 & 0.769 \\
Idiosyncratic risk & 76,392 & 0.037 & 0.031 & 0.023 & 0.010 & 0.129 \\
Systematic risk & 76,392 & 0.007 & 0.006 & 0.006 & 0.000 & 0.033 \\
Firm age & 76,392 & 14.720 & 10.000 & 14.422 & 1.000 & 83.000 \\
\hline
\end{tabular}

Panel B. Financial Distress and Firm Survival

\begin{tabular}{lcccccc}
\hline & $N$ & Mean & Median & St. Dev. & Min & Max \\
Interest coverage & 56,088 & 2.169 & 1.923 & 1.035 & 0.758 & 5.909 \\
Z-score - Dummy & 76,392 & 0.843 & 1.000 & 0.364 & 0.000 & 1.000 \\
Zmijewski-score & 76,392 & -1.179 & -1.445 & 1.882 & -4.118 & 7.545 \\
O-score & 76,392 & -3.763 & -4.121 & 2.635 & -9.083 & 6.505 \\
Distance to default & 76,392 & 6.423 & 5.175 & 5.575 & -1.737 & 27.904 \\
Default probability & 76,392 & 6.759 & 0.000 & 18.928 & 0.000 & 95.882 \\
CHS-score & 76,392 & -6.923 & -7.509 & 1.895 & -9.117 & 1.304 \\
Default probability (CHS) & 76,392 & 1.963 & 0.055 & 9.873 & 0.011 & 78.658 \\
Merger and acquisition (year +5) & 76,392 & 0.187 & 0.000 & 0.390 & 0.000 & 1.000 \\
Exchange transaction (year +5) & 76,392 & 0.010 & 0.000 & 0.098 & 0.000 & 1.000 \\
Liquidation (year +5) & 76,392 & 0.003 & 0.000 & 0.052 & 0.000 & 1.000 \\
Exchange dropped (year +5) & 76,392 & 0.138 & 0.000 & 0.345 & 0.000 & 1.000 \\
Liquidation and Exchange dropped & 76,392 & 0.141 & 0.000 & 0.348 & 0.000 & 1.000 \\
(year +5) & 70,790 & 0.049 & 0.000 & 0.216 & 0.000 & 1.000 \\
Bankruptcy (year +5) & & & & &
\end{tabular}

Panel C. Institutional Ownership

\begin{tabular}{lcccccc}
\hline & $N$ & Mean & Median & St. Dev. & Min & Max \\
Institutional ownership & 51,917 & 0.347 & 0.297 & 0.271 & 0.001 & 0.952 \\
$\begin{array}{l}\text { Investor turnover } \\
\text { Low turnover institutional }\end{array}$ & 51,917 & 0.193 & 0.190 & 0.063 & 0.045 & 0.419 \\
ownership & 51,917 & 0.062 & 0.039 & 0.068 & 0.000 & 0.315
\end{tabular}




\begin{tabular}{lcccccc}
$\begin{array}{l}\text { Mid turnover institutional } \\
\text { ownership }\end{array}$ & 51,917 & 0.153 & 0.122 & 0.137 & 0.000 & 0.537 \\
$\begin{array}{l}\text { High turnover institutional } \\
\text { ownership }\end{array}$ & 51,917 & 0.125 & 0.085 & 0.129 & 0.000 & 0.532 \\
$\begin{array}{l}\text { Ownership of dedicated } \\
\text { institutions }\end{array}$ & 51,917 & 0.048 & 0.018 & 0.065 & 0.000 & 0.303 \\
$\begin{array}{l}\text { Ownership of quasi-indexer } \\
\text { institutions }\end{array}$ & 51,917 & 0.220 & 0.182 & 0.181 & 0.000 & 0.676 \\
\hline
\end{tabular}




\section{Table 2. Payout Tobit models}

This table presents Tobit regression results on a panel dataset of firm-year total payout and a set of established payout determinants for all US-listed firms during 1975-2008, as per the following equation:

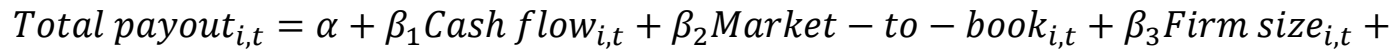
$\beta_{4}$ Leverage $_{i, t}+\beta_{5}$ Retained earning $_{i, t}+\beta_{6}$ Cash holdings $_{i, t}+\beta_{7}$ Idiosyncratic ris $_{i, t}+$ $\beta_{8}$ Systematic risk $_{i, t}+\beta_{9}$ Firm age $_{i, t}+u_{i, t}$

We exclude financial firms (SIC codes 6000-6999), utilities (SIC codes 4900-4949), and securities other than common stock. All variables are defined in the Appendix. The regression includes industry, as defined using the Fama-French 49 industries classification, and year controls. We use heteroskedasticity robust standard errors clustered by firm to control for within-firm (serial) correlation. The robust standard errors are reported in parentheses. $* * *, * *$, and $*$ denote significance at $1 \%, 5 \%$, and $10 \%$, respectively.

\section{Total payout}

Cash flow

$0.021 * * *$

Market-to-book

$-0.009 * * *$

Firm size

$0.006 * * *$

(0.000)

Leverage

$-0.002$

$(0.003)$

Retained earnings

$0.006 * * *$

Cash holdings

$(0.001)$

$0.025 * * *$

$(0.003)$

Idiosyncratic risk

$-0.593 * * *$

$(0.032)$

Systematic risk

$-1.018^{* * *}$

$(0.075)$

Firm age

$0.001 * * *$

Constant

$(0.000)$

$0.016^{* * * *}$

Industry \& Year dummies

(0.006)

YES 
Table 3. Non-payers, under-payers, moderate-payers, and over-payers

This table presents the average actual and expected payout yields for all US-listed firms during 19752008. We exclude financial firms (SIC codes 6000-6999), utilities (SIC codes 4900-4949), and securities other than common stock. Panel A reports the firm-specific characteristics and differences in means for firms that pay out on year $t$ less (under-payers) or more (over-payers) than expected based on the expected (fitted) payout yield estimated from the Tobit regression as shown in Table 2. All variables are defined in the Appendix. Panel B reports the average actual and expected payout yield. The payout yield is the total payout (measured as the sum of dividends and share repurchases) scaled by market capitalization. The expected payout yield is the predicted (fitted) payout yield estimated from the Tobit regression as shown in Table 2. Based on the expected payout yield we use three alternative classifications to identify over-payers and under-payers. The Mid-point classification identifies firm $i$ at year $t$ as an over-payer if the residual $\mathrm{u}_{\mathrm{i}, \mathrm{t}}$ is positive, as an under-payer if the residual $\mathrm{u}_{\mathrm{i}, \mathrm{t}}$ is negative, and as a non-payer if there is no payout at year $t$. The Terciles classification identifies firm $i$ at year $t$ as an overpayer if the residual $\mathrm{u}_{\mathrm{i}, \mathrm{t}}$ is in the top tercile, as a moderate-payer if the residual $\mathrm{u}_{\mathrm{i}, \mathrm{t}}$ is in the middle tercile, as an under-payer if the residual $\mathrm{u}_{\mathrm{i}, \mathrm{t}}$ is in the lower tercile, and as a non-payer if there is no payout at year $t$. The Persistent classification identifies firm $i$ at year $t$ as an over-payer if the residual $\mathrm{u}_{\mathrm{i}, \mathrm{t}}$ is positive over three consecutive years, as an under-payer if the residual $\mathrm{u}_{\mathrm{i}, \mathrm{t}}$ is negative over three consecutive years, as a non-payer if there is no payout over three consecutive years, and all other payers are labelled as unclassified. $* * *, * *$, and $*$ denote significance at $1 \%, 5 \%$, and $10 \%$, respectively.

\begin{tabular}{lcccc}
\hline Panel A & $\begin{array}{c}\text { Under-payers } \\
(N=23,740)\end{array}$ & $\begin{array}{c}\text { Over-Payers } \\
(N=17,035)\end{array}$ & $\begin{array}{c}\text { Difference in } \\
\text { means }\end{array}$ & t-stat \\
\hline Cash flow & 0.143 & 0.119 & $0.024 * * *$ & $(17.955)$ \\
Market-to-book & 1.607 & 1.433 & $0.174 * * *$ & $(17.320)$ \\
Firm size & 5.384 & 4.586 & $0.798 * * *$ & $(39.296)$ \\
Leverage & 0.168 & 0.191 & $-0.024 * * *$ & $(-15.202)$ \\
Retained earnings & 0.240 & 0.144 & $0.096 * * *$ & $(14.697)$ \\
Cash holdings & 0.103 & 0.107 & $-0.004 * * *$ & $(-2.957)$ \\
Idiosyncratic risk & 0.026 & 0.031 & $-0.005 * * *$ & $(-26.521)$ \\
Systematic risk & 0.007 & 0.007 & $0.000 * * *$ & $(8.264)$ \\
Firm Age & 20.363 & 17.035 & $3.328 * * *$ & $(20.953)$ \\
Total payout & 0.018 & 0.076 & $-0.058^{*} * *$ & $(-124.601)$
\end{tabular}

\begin{tabular}{llll}
\hline Panel B & N & Mean (actual) payout yield & Mean (expected) payout yield \\
\hline
\end{tabular}

Mid-point classification

Non-payers

35,617

23,740

17,035

Over-payers

Terciles classification

Non-payers

Under-payers

Moderate-payers

Over-payers

Persistent classification

Non-payers

Under-payers

Unclassified-payers

Over-payers
35,617

13,592

13,592

13,591

13,718

7,714

19,876

3,932
0.000

0.018

0.076

0.000

0.016

0.024

0.087
0.015

0.035

0.031

0.000

0.016

0.020

0.041

0.034

0.029

0.076

0.034

0.041

0.029

0.032 
Table 4. Total payout and financial distress.

This table presents the average values for a range of financial distress variables for all US-listed firms during 1975-2008. We exclude financial firms (SIC codes 6000-6999), utilities (SIC codes 4900-4949), and securities other than common stock. The average values and the differences in means are reported for each firm type based on three alternative classifications: the Mid-point, the Terciles, and the Persistent classifications. These classifications are defined in Table 3. All variables are defined in the Appendix. $* * *, * *$, and $*$ denote significance at $1 \%, 5 \%$, and $10 \%$, respectively.

\begin{tabular}{|c|c|c|c|c|c|c|}
\hline & $\begin{array}{l}\text { Non- } \\
\text { pavers }\end{array}$ & $\begin{array}{l}\text { Under- } \\
\text { pavers }\end{array}$ & $\begin{array}{c}\text { Moderate/ } \\
\text { Unclassified } \\
\text { Pavers }\end{array}$ & $\begin{array}{l}\text { Over- } \\
\text { pavers }\end{array}$ & \multicolumn{2}{|c|}{ Difference in means } \\
\hline & & & & & (4) vs. (1) & (4) vs. (2) \\
\hline \multicolumn{7}{|c|}{ Interest Coverage } \\
\hline Mid-point & 2.004 & 2.291 & - & 2.231 & $0.227 * * *$ & $-0.059 * * *$ \\
\hline Terciles & 2.004 & 2.286 & 2.293 & 2.219 & $0.215^{* * *}$ & $-0.068 * * *$ \\
\hline Persistent & 1.963 & 2.333 & 2.149 & 2.209 & $0.246 * * *$ & $-0.125 * * *$ \\
\hline \multicolumn{7}{|c|}{ Z-Score - Dummy } \\
\hline Mid-point & 0.760 & 0.931 & - & 0.892 & $0.131 * * *$ & $-0.040 * * *$ \\
\hline Terciles & 0.760 & 0.941 & 0.914 & 0.889 & $0.129 * * *$ & $-0.052 * * *$ \\
\hline Persistent & 0.761 & 0.951 & 0.874 & 0.929 & $0.168 * * *$ & $-0.022 * * *$ \\
\hline \multicolumn{7}{|c|}{ Zmijewski-score } \\
\hline Mid-point & -0.750 & -1.652 & - & -1.416 & $-0.667 * * *$ & $0.236 * * *$ \\
\hline Terciles & -0.750 & -1.673 & -1.577 & -1.411 & $-0.661 * * *$ & $0.262 * * *$ \\
\hline Persistent & -0.798 & -1.724 & -1.345 & -1.464 & $-0.667 * * *$ & $0.260 * * *$ \\
\hline \multicolumn{7}{|c|}{ O-score } \\
\hline Mid-point & -2.833 & -4.799 & - & -4.264 & $-1.432 * * *$ & $0.534 * * *$ \\
\hline Terciles & -2.833 & -5.005 & -4.454 & -4.267 & $-1.435 * * *$ & $0.738 * * *$ \\
\hline Persistent & -3.024 & -5.139 & -4.176 & -4.410 & $-1.387 * * *$ & $0.729 * * *$ \\
\hline \multicolumn{7}{|c|}{ Default probability } \\
\hline Mid-point & 10.455 & 2.255 & - & 5.309 & $-5.146^{* * *}$ & $3.053 * * *$ \\
\hline Terciles & 10.455 & 1.666 & 3.232 & 5.694 & $-4.761 * * *$ & $4.028 * * *$ \\
\hline Persistent & 10.642 & 1.444 & 6.195 & 3.612 & $-7.030 * * *$ & $2.167 * * *$ \\
\hline \multicolumn{7}{|c|}{ Default probability (CHS) } \\
\hline Mid-point & 3.409 & 0.307 & - & 1.247 & $-2.162 * * *$ & $0.940 * * *$ \\
\hline Terciles & 3.409 & 0.122 & 0.713 & 1.264 & $-2.145 * * *$ & $1.142 * * *$ \\
\hline Persistent & 2.993 & 0.134 & 1.207 & 0.572 & $-2.421 * * *$ & $0.437 * * *$ \\
\hline
\end{tabular}




\section{Table 5. Total payout and firm survival.}

Panels A and B of this table present the average values for a range of firm voluntary and involuntary delisting probabilities for all US-listed firms during 1975-2008. Panel C contains the average value of a firm's probability to be involved in a bankruptcy case for the sample period 1980-2008. We exclude financial firms (SIC codes 6000-6999), utilities (SIC codes 4900-4949), and securities other than common stock. As in Bhattacharya et al. (2015) we consider two types of delistings: voluntary and involuntary. As voluntary delistings we consider firms that are involved in (a) Mergers and acquisitions and (b) Exchange Transactions. As involuntary delistings we consider firms that are (c) liquidated, where firms are forced to cease operations and sell their assets (Liquidation); (d) dropped from a stock exchange, where firms are dropped for reasons other than liquidation or voluntary delisting (Exchange dropped); and (e) a combination of firms that are liquidated or dropped from the exchange (Liquidation and Exchange dropped). We consider both Chapter 7 and Chapter 11 cases to measure bankruptcy probability. The average values of the delisting and bankruptcy dummies and the differences in means are reported for each firm type based on three alternative classifications: the Mid-point, the Terciles, and the Persistent classifications. These classifications are defined in Table 3. All firm survival variables are defined in the Appendix and are computed over the five years following the current period $(\mathrm{t}) . * * *, * *$, and $*$ denote significance at $1 \%, 5 \%$, and $10 \%$, respectively.

\begin{tabular}{|c|c|c|c|c|c|c|}
\hline & $\begin{array}{c}\text { Non- } \\
\text { payers (1) }\end{array}$ & $\begin{array}{c}\text { Under-payers } \\
\text { (2) }\end{array}$ & $\begin{array}{c}\text { Moderate/ } \\
\text { Unclassified } \\
\text { Payers (3) }\end{array}$ & $\begin{array}{c}\text { Over-payers } \\
\text { (4) }\end{array}$ & \multicolumn{2}{|c|}{ Difference in means } \\
\hline & & & & & (4) vs. (1) & (4) vs. (2) \\
\hline \multicolumn{7}{|c|}{ Panel A. Voluntary delisting } \\
\hline \multicolumn{7}{|c|}{ Merger and acquisition (year +5 ) } \\
\hline Mid-point & 0.187 & 0.186 & - & 0.189 & 0.002 & 0.004 \\
\hline Terciles & 0.187 & 0.181 & 0.190 & 0.190 & 0.003 & $0.009 *$ \\
\hline Persistent & 0.189 & 0.167 & 0.195 & 0.180 & -0.009 & $0.013 *$ \\
\hline \multicolumn{7}{|c|}{ Exchange transaction $($ year +5$)$} \\
\hline Mid-point & 0.006 & 0.013 & - & 0.013 & $0.007 * * *$ & 0.001 \\
\hline Terciles & 0.006 & 0.012 & 0.014 & 0.012 & $0.006 * * *$ & 0.000 \\
\hline Persistent & 0.005 & 0.013 & 0.010 & 0.016 & $0.011 * * *$ & 0.003 \\
\hline
\end{tabular}

Panel B. Involuntary delisting

\begin{tabular}{lcccccc}
\hline \multicolumn{7}{c}{ Liquidation (year +5) } \\
\hline Mid-point & 0.002 & 0.003 & - & 0.003 & $0.001^{*}$ & 0.001 \\
Terciles & 0.002 & 0.003 & 0.003 & 0.003 & 0.001 & 0.001 \\
Persistent & 0.002 & 0.002 & 0.002 & 0.001 & -0.000 & $-0.001^{*}$ \\
\hline \multicolumn{7}{c}{ Exchange dropped (year +5) } \\
\hline Mid-point & 0.224 & 0.049 & - & 0.082 & $-0.142^{* * *}$ & $0.033^{* * *}$ \\
Terciles & 0.224 & 0.033 & 0.072 & 0.083 & $-0.142^{* * *}$ & $0.049^{* * *}$ \\
Persistent & 0.203 & 0.024 & 0.100 & 0.051 & $-0.152^{* * *}$ & $0.027^{* * *}$ \\
\hline \multicolumn{7}{c}{ Liquidation and Exchange dropped (year +5$)$} \\
\hline Mid-point & 0.227 & 0.051 & - & 0.085 & $-0.141^{* * *}$ & $0.034^{* * *}$ \\
Terciles & 0.227 & 0.036 & 0.075 & 0.086 & $-0.141^{* * *}$ & $0.050^{* * *}$ \\
Persistent & 0.203 & 0.024 & 0.100 & 0.051 & $-0.152^{* * *}$ & $0.027^{* * *}$ \\
\hline
\end{tabular}


Panel C. Bankruptcy

\begin{tabular}{lllcccc}
\hline \multicolumn{7}{c}{ Bankruptcy $($ year +5$)$} \\
\hline Mid-point & 0.065 & 0.030 & - & 0.039 & $-0.027 * * *$ & $0.009 * * *$ \\
Terciles & 0.065 & 0.027 & 0.033 & 0.040 & $-0.025^{* * *}$ & $0.013^{* * *}$ \\
Persistent & 0.065 & 0.020 & 0.049 & 0.030 & $-0.035^{* * *}$ & $0.009 * * *$ \\
\hline
\end{tabular}




\section{Table 6. Covariate matching.}

This table reports the results on the average treatment effect on the treated (ATT) for an array of financial distress variables, an involuntary delisting measure, and a bankruptcy variable for all US-listed firms during 1975-2008. Both the delisting and bankruptcy measures are computed over the five years following the current period (t). We exclude financial firms (SIC codes 6000-6999), utilities (SIC codes 4900-4949), and securities other than common stock. The Mid-point classification (see Table 3) is used for matching each firm-year observation of an over-payer (treated) with a suitable under-payer (untreated), by using the one-to-one nearest neighbor covariate matching method with replacement. Nonpayers are excluded from the matching process. $\Gamma$ indicates the level of hidden bias, based on the Rosenbaum bounds (Rosenbaum, 2002), that is required for invalidating the statistical significance (at the 90\% confidence level) of the treatment effect on the outcome. Panel A reports the results on matching treated and untreated firms based on the expected level of payout. Panel B reports the results on matching treated and untreated firms based on the similarity of the firm-specific characteristics (all controls), relying on the non-binary independent variables of the Tobit regression as shown in Table 2. All variables are defined in the Appendix. t-statistics are reported in parentheses. $* * *, * *$, and $*$ denote significance at $1 \%, 5 \%$, and $10 \%$, respectively.

\begin{tabular}{|c|c|c|c|c|c|c|}
\hline Panel A. Expected Only & $\begin{array}{l}\text { No of } \\
\text { treated }\end{array}$ & $\begin{array}{c}\text { Bias } \\
\text { before }\end{array}$ & $\begin{array}{l}\text { Bias } \\
\text { after }\end{array}$ & ATT & t-stat & $\Gamma$ \\
\hline Interest Coverage & 14,147 & 19.938 & 0.001 & $-0.051 * * *$ & $(-3.505)$ & 1.09 \\
\hline Z-Score - Dummy & 17,035 & 24.342 & 0.001 & $-0.028 * * *$ & $(-7.313)$ & 1.42 \\
\hline Zmijewski-score & 17,035 & 24.342 & 0.001 & $0.172 * * *$ & $(8.999)$ & 1.17 \\
\hline O-score & 17,035 & 24.342 & 0.001 & $0.331 * * *$ & $(12.186)$ & 1.32 \\
\hline Default probability & 17,035 & 24.342 & 0.001 & $2.478 * * *$ & $(13.348)$ & 1.46 \\
\hline Default probability (CHS) & 17,035 & 24.342 & 0.001 & $0.751 * * *$ & $(9.912)$ & 1.62 \\
\hline Liquidation and Exchange dropped (year +5$)$ & 17,035 & 24.342 & 0.001 & $0.019 * * *$ & $(5.518)$ & 1.40 \\
\hline Bankruptcy $($ year +5$)$ & 15,244 & 22.589 & 0.001 & $0.006 * *$ & $(2.144)$ & 1.09 \\
\hline Panel B. All Controls & $\begin{array}{l}\text { No of } \\
\text { treated }\end{array}$ & $\begin{array}{c}\text { Bias } \\
\text { before }\end{array}$ & $\begin{array}{l}\text { Bias } \\
\text { after }\end{array}$ & ATT & t-stat & $\Gamma$ \\
\hline Interest Coverage & 14,147 & 15.792 & 1.884 & $0.038 * * *$ & $(2.570)$ & 1.07 \\
\hline Z-Score - Dummy & 17,035 & 18.403 & 2.425 & $-0.021 * * *$ & $(-5.477)$ & 1.37 \\
\hline Zmijewski-score & 17,035 & 18.403 & 2.425 & $0.120 * * *$ & $(6.313)$ & 1.16 \\
\hline O-score & 17,035 & 18.403 & 2.425 & $0.179 * * *$ & $(6.612)$ & 1.25 \\
\hline Default probability & 17,035 & 18.403 & 2.425 & $1.440 * * *$ & $(7.370)$ & 1.28 \\
\hline Default probability (CHS) & 17,035 & 18.403 & 2.425 & $0.654 * * *$ & $(8.451)$ & 1.62 \\
\hline Liquidation and Exchange dropped $($ year +5$)$ & 17,035 & 18.403 & 2.425 & $0.012 * * *$ & $(3.394)$ & 1.26 \\
\hline Bankruptcy $($ year +5$)$ & 15,244 & 17.248 & 2.423 & 0.001 & $(0.483)$ & 1.04 \\
\hline
\end{tabular}




\section{Table 7. Transition across the financial distress spectrum}

This table presents a transition analysis across different levels of financial distress for the reduced sample of over-payers and under-payers (i.e., excluding non-payers) based on the Mid-point classification (see Table 3). We use a panel dataset of all US-listed firms during 1975-2008. We exclude financial firms (SIC codes 6000-6999), utilities (SIC codes 4900-4949), and securities other than common stock. The tables report the transition frequencies with the transition probabilities reported in parentheses. The rows provide the initial values of financial distress while the columns provide the final values, i.e., the transition to the next state of financial distress one step ahead. The results are reported for the two groups of under-payers and over-payers respectively. Panels A, B, and C report the transition of under-payers and over-payers based on Z-score-dummy, Default Probability, and Default Probability (CHS) respectively. For Z-score - dummy we only consider two states (i.e., the dummy is equal to one or zero) since this is a binary variable. States for the other two variables are based on quintiles (from one indicating the minimum level of distress to five indicating the maximum level of distress). All variables are defined in the Appendix.

\begin{tabular}{|c|c|c|c|c|c|c|}
\hline \multicolumn{7}{|c|}{ Panel A. Z-Score - Dummy } \\
\hline & \multicolumn{3}{|c|}{ Under-payers } & \multicolumn{3}{|c|}{ Over-payers } \\
\hline & $\begin{array}{c}\text { Z-Score - } \\
\text { Dummy }=0\end{array}$ & $\begin{array}{c}\text { Z-Score - } \\
\text { Dummy = } 1\end{array}$ & Total & $\begin{array}{c}\text { Z-Score - } \\
\text { Dummy }=0\end{array}$ & $\begin{array}{c}\text { Z-Score - } \\
\text { Dummy = } 1\end{array}$ & Total \\
\hline Z-Score - Dummy $=0$ & $\begin{array}{c}449 \\
(68.76)\end{array}$ & $\begin{array}{c}204 \\
(31.24)\end{array}$ & $\begin{array}{c}653 \\
(100.00)\end{array}$ & $\begin{array}{c}448 \\
(78.18)\end{array}$ & $\begin{array}{c}125 \\
(21.82)\end{array}$ & $\begin{array}{c}573 \\
(100.00)\end{array}$ \\
\hline Z-Score - Dummy $=1$ & $\begin{array}{c}326 \\
(2.47)\end{array}$ & $\begin{array}{r}12,853 \\
(97.53)\end{array}$ & $\begin{array}{c}13,179 \\
(100.00)\end{array}$ & $\begin{array}{c}279 \\
(3.66)\end{array}$ & $\begin{array}{c}7,346 \\
(96.34)\end{array}$ & $\begin{array}{c}7,625 \\
(100.00)\end{array}$ \\
\hline Total & $\begin{array}{c}775 \\
(5.60)\end{array}$ & $\begin{array}{l}13,057 \\
(94.40)\end{array}$ & $\begin{array}{c}13,832 \\
(100.00)\end{array}$ & $\begin{array}{c}727 \\
(8.87)\end{array}$ & $\begin{array}{c}7,471 \\
(91.13)\end{array}$ & $\begin{array}{c}8,198 \\
(100.00)\end{array}$ \\
\hline
\end{tabular}

Panel B. Default Probability

\begin{tabular}{|c|c|c|c|c|c|c|c|c|c|c|c|c|c|}
\hline & \multicolumn{6}{|c|}{ Under-payers } & \multicolumn{7}{|c|}{ Over-payers } \\
\hline & 1 & 2 & 3 & 4 & 5 & Total & & 1 & 2 & 3 & 4 & 5 & Total \\
\hline 1 & $\begin{array}{c}1,959 \\
(57.50)\end{array}$ & $\begin{array}{c}832 \\
(24.42)\end{array}$ & $\begin{array}{c}393 \\
(11.54)\end{array}$ & $\begin{array}{c}165 \\
(4.84)\end{array}$ & $\begin{array}{c}58 \\
(1.70)\end{array}$ & $\begin{array}{c}3,407 \\
(100.00)\end{array}$ & 1 & $\begin{array}{c}989 \\
(55.19)\end{array}$ & $\begin{array}{c}419 \\
(23.38)\end{array}$ & $\begin{array}{c}217 \\
(12.11)\end{array}$ & $\begin{array}{c}115 \\
(6.42)\end{array}$ & $\begin{array}{c}52 \\
(2.90)\end{array}$ & $\begin{array}{c}1,792 \\
(100.00)\end{array}$ \\
\hline 2 & $\begin{array}{c}972 \\
(27.87) \\
\end{array}$ & $\begin{array}{c}1,121 \\
(32.15)\end{array}$ & $\begin{array}{c}764 \\
(21.91) \\
\end{array}$ & $\begin{array}{c}480 \\
(13.77)\end{array}$ & $\begin{array}{c}150 \\
(4.30)\end{array}$ & $\begin{array}{c}3,487 \\
(100.00)\end{array}$ & 2 & $\begin{array}{c}409 \\
(25.63) \\
\end{array}$ & $\begin{array}{c}459 \\
(28.76) \\
\end{array}$ & $\begin{array}{c}367 \\
(22.99)\end{array}$ & $\begin{array}{c}246 \\
(15.41)\end{array}$ & $\begin{array}{c}115 \\
(7.21)\end{array}$ & $\begin{array}{c}1,596 \\
(100.00)\end{array}$ \\
\hline 3 & $\begin{array}{c}381 \\
(12.89) \\
\end{array}$ & $\begin{array}{c}799 \\
(27.03) \\
\end{array}$ & $\begin{array}{c}848 \\
(28.69) \\
\end{array}$ & $\begin{array}{c}625 \\
(21.14) \\
\end{array}$ & $\begin{array}{c}303 \\
(10.25)\end{array}$ & $\begin{array}{c}2,956 \\
(100.00)\end{array}$ & 3 & $\begin{array}{c}189 \\
(11.41)\end{array}$ & $\begin{array}{c}375 \\
(22.64)\end{array}$ & $\begin{array}{c}427 \\
(25.79)\end{array}$ & $\begin{array}{c}391 \\
(23.61)\end{array}$ & $\begin{array}{c}274 \\
(16.55) \\
\end{array}$ & $\begin{array}{c}1,656 \\
(100.00)\end{array}$ \\
\hline 4 & $\begin{array}{c}145 \\
(5.70) \\
\end{array}$ & $\begin{array}{c}429 \\
(16.85) \\
\end{array}$ & $\begin{array}{c}659 \\
(25.88) \\
\end{array}$ & $\begin{array}{c}757 \\
(29.73) \\
\end{array}$ & $\begin{array}{c}556 \\
(21.84) \\
\end{array}$ & $\begin{array}{c}2,546 \\
(100.00) \\
\end{array}$ & 4 & $\begin{array}{c}85 \\
(4.96) \\
\end{array}$ & $\begin{array}{c}222 \\
(12.97) \\
\end{array}$ & $\begin{array}{c}385 \\
(22.49) \\
\end{array}$ & $\begin{array}{c}526 \\
(30.72) \\
\end{array}$ & $\begin{array}{c}494 \\
(28.86) \\
\end{array}$ & $\begin{array}{c}1,712 \\
(100.00) \\
\end{array}$ \\
\hline 5 & 36 & 107 & 221 & 424 & 648 & 1,436 & 5 & 22 & 65 & 192 & 355 & 808 & 1,442 \\
\hline
\end{tabular}




\begin{tabular}{|c|c|c|c|c|c|c|c|c|c|c|c|c|c|}
\hline & $(2.51)$ & $(7.45)$ & $(15.39)$ & $(29.53)$ & (45.13) & (100.00) & & (1.53) & $(4.51)$ & (13.31) & (24.62) & $(56.03)$ & $(100.00)$ \\
\hline Total & $\begin{array}{c}3,493 \\
(25.25)\end{array}$ & $\begin{array}{c}3,288 \\
(23.77)\end{array}$ & $\begin{array}{c}2,885 \\
(20.86)\end{array}$ & $\begin{array}{c}2,451 \\
(17.72)\end{array}$ & $\begin{array}{c}1,715 \\
(12.40)\end{array}$ & $\begin{array}{c}13,832 \\
(100.00)\end{array}$ & Tot & $\begin{array}{c}1,694 \\
(20.66)\end{array}$ & $\begin{array}{c}1,540 \\
(18.79)\end{array}$ & $\begin{array}{c}1,588 \\
(19.37)\end{array}$ & $\begin{array}{c}1,633 \\
(19.92)\end{array}$ & $\begin{array}{c}1,743 \\
(21.26)\end{array}$ & $\begin{array}{c}8,198 \\
(100.00)\end{array}$ \\
\hline
\end{tabular}

Panel C. Default Probability (CHS)

\begin{tabular}{|c|c|c|c|c|c|c|c|c|c|c|c|c|c|}
\hline & \multicolumn{6}{|c|}{ Under-payers } & \multicolumn{7}{|c|}{ Over-payers } \\
\hline & 1 & 2 & 3 & 4 & 5 & Total & & 1 & 2 & 3 & 4 & 5 & Total \\
\hline 1 & $\begin{array}{c}2,203 \\
(57.84)\end{array}$ & $\begin{array}{c}938 \\
(24.63)\end{array}$ & $\begin{array}{c}447 \\
(11.74)\end{array}$ & $\begin{array}{c}172 \\
(4.52)\end{array}$ & $\begin{array}{c}49 \\
(1.29)\end{array}$ & $\begin{array}{l}3,809 \\
(100)\end{array}$ & 1 & $\begin{array}{c}662 \\
(46.33)\end{array}$ & $\begin{array}{c}394 \\
(27.57)\end{array}$ & $\begin{array}{c}223 \\
(15.61)\end{array}$ & $\begin{array}{c}104 \\
(7.28)\end{array}$ & $\begin{array}{c}46 \\
(3.22)\end{array}$ & $\begin{array}{l}1,429 \\
(100)\end{array}$ \\
\hline 2 & $\begin{array}{c}927 \\
(26.46)\end{array}$ & $\begin{array}{c}1,244 \\
(35.51)\end{array}$ & $\begin{array}{c}826 \\
(23.58)\end{array}$ & $\begin{array}{c}404 \\
(11.53) \\
\end{array}$ & $\begin{array}{c}102 \\
(2.91)\end{array}$ & $\begin{array}{l}3,503 \\
(100)\end{array}$ & 2 & $\begin{array}{c}303 \\
(18.09) \\
\end{array}$ & $\begin{array}{c}559 \\
(33.37) \\
\end{array}$ & $\begin{array}{c}444 \\
(26.51)\end{array}$ & $\begin{array}{c}256 \\
(15.28) \\
\end{array}$ & $\begin{array}{c}113 \\
(6.75) \\
\end{array}$ & $\begin{array}{l}1,675 \\
(100)\end{array}$ \\
\hline 3 & $\begin{array}{c}377 \\
(12.45) \\
\end{array}$ & $\begin{array}{c}803 \\
(26.53) \\
\end{array}$ & $\begin{array}{c}934 \\
(30.86) \\
\end{array}$ & $\begin{array}{c}680 \\
(22.46) \\
\end{array}$ & $\begin{array}{c}233 \\
(7.7) \\
\end{array}$ & $\begin{array}{l}3,027 \\
(100)\end{array}$ & 3 & $\begin{array}{c}141 \\
(7.95)\end{array}$ & $\begin{array}{c}380 \\
(21.42)\end{array}$ & $\begin{array}{c}544 \\
(30.67)\end{array}$ & $\begin{array}{c}490 \\
(27.62)\end{array}$ & $\begin{array}{c}219 \\
(12.34)\end{array}$ & $\begin{array}{l}1,774 \\
(100)\end{array}$ \\
\hline 4 & $\begin{array}{c}139 \\
(5.89) \\
\end{array}$ & $\begin{array}{c}333 \\
(14.1) \\
\end{array}$ & $\begin{array}{c}609 \\
(25.79) \\
\end{array}$ & $\begin{array}{c}809 \\
(34.27) \\
\end{array}$ & $\begin{array}{c}471 \\
(19.95) \\
\end{array}$ & $\begin{array}{l}2,361 \\
(100) \\
\end{array}$ & 4 & $\begin{array}{c}80 \\
(4.13) \\
\end{array}$ & $\begin{array}{c}194 \\
(10.03) \\
\end{array}$ & $\begin{array}{c}391 \\
(20.21)\end{array}$ & $\begin{array}{c}683 \\
(35.3) \\
\end{array}$ & $\begin{array}{c}587 \\
(30.34) \\
\end{array}$ & $\begin{array}{l}1,935 \\
(100) \\
\end{array}$ \\
\hline 5 & $\begin{array}{c}39 \\
(3.45) \\
\end{array}$ & $\begin{array}{c}57 \\
(5.04) \\
\end{array}$ & $\begin{array}{c}128 \\
(11.31)\end{array}$ & $\begin{array}{c}349 \\
(30.83) \\
\end{array}$ & $\begin{array}{c}559 \\
(49.38)\end{array}$ & $\begin{array}{l}1,132 \\
(100)\end{array}$ & 5 & $\begin{array}{c}30 \\
(2.17)\end{array}$ & $\begin{array}{c}45 \\
(3.25) \\
\end{array}$ & $\begin{array}{c}100 \\
(7.22) \\
\end{array}$ & $\begin{array}{c}333 \\
(24.04)\end{array}$ & $\begin{array}{c}877 \\
(63.32) \\
\end{array}$ & $\begin{array}{l}1,385 \\
(100)\end{array}$ \\
\hline Total & $\begin{array}{c}3,685 \\
(26.64)\end{array}$ & $\begin{array}{l}3,375 \\
(24.4)\end{array}$ & $\begin{array}{c}2,944 \\
(21.28)\end{array}$ & $\begin{array}{c}2,414 \\
(17.45)\end{array}$ & $\begin{array}{c}1,414 \\
(10.22)\end{array}$ & $\begin{array}{c}13,832 \\
(100)\end{array}$ & Total & $\begin{array}{c}1,216 \\
(14.83)\end{array}$ & $\begin{array}{c}1,572 \\
(19.18)\end{array}$ & $\begin{array}{c}1,702 \\
(20.76)\end{array}$ & $\begin{array}{c}1,866 \\
(22.76)\end{array}$ & $\begin{array}{c}1,842 \\
(22.47)\end{array}$ & $\begin{array}{l}8,198 \\
(100)\end{array}$ \\
\hline
\end{tabular}


Table 8. Transition between underpayment and overpayment for a given distress level.

This table presents the transition between overpayment and underpayment for the reduced sample of over-payers and under-payers (i.e., excluding non-payers) based on the Mid-point classification (see Table 3). We use a panel dataset of all US-listed firms during 1975-2008. We exclude financial firms (SIC codes 6000-6999), utilities (SIC codes 4900-4949), and securities other than common stock. The table reports the transition frequencies with the transition probabilities reported in parentheses. The rows provide the initial payout state of the firm (under-payer or overpayer) while the columns provide the final state, i.e., the transition to the next payout state one step ahead. Panels A, B, and C report the transition results for the two values of the Z-score - Dummy, the first and fifth quintiles for Default Probability, and the same quintiles for Default Probability (CHS) respectively. All variables are defined in the Appendix.

\begin{tabular}{|c|c|c|c|c|c|c|}
\hline \multicolumn{7}{|c|}{ Panel A. Z-Score - Dummy } \\
\hline & \multicolumn{3}{|c|}{ Z-Score-Dummy $=1$} & \multicolumn{3}{|c|}{ Z-Score - Dummy $=0$} \\
\hline & Under-payers & Over-payers & Total & Under-payers & Over-payers & Total \\
\hline \multirow{2}{*}{ Under-payers } & 12,853 & 4,200 & 17,053 & 449 & 194 & 643 \\
\hline & (75.37) & (24.63) & $(100.00)$ & (69.83) & (30.17) & $(100.00)$ \\
\hline \multirow[t]{2}{*}{ Over-payers } & 4,066 & 7,346 & 11,412 & 213 & 448 & 661 \\
\hline & (35.63) & (64.37) & (100.00) & $(32.22)$ & $(67.78)$ & (100.00) \\
\hline \multirow[t]{2}{*}{ Total } & 16,919 & 11,546 & 28,465 & 662 & 642 & 1,304 \\
\hline & (59.44) & $(40.56)$ & $(100.00)$ & $(50.77)$ & (49.23) & $(100.00)$ \\
\hline
\end{tabular}

Panel B. Default Probability

\begin{tabular}{|c|c|c|c|c|c|c|}
\hline & \multicolumn{3}{|c|}{$\begin{array}{c}\text { Default Probability } \\
I^{\text {st }} \text { Quintile }\end{array}$} & \multicolumn{3}{|c|}{$\begin{array}{l}\text { Default Probability } \\
5^{\text {th }} \text { Quintile }\end{array}$} \\
\hline & Under-payers & Over-payers & Total & Under-payers & Over-payers & Total \\
\hline Under-payers & $\begin{array}{c}1,959 \\
(78.00)\end{array}$ & $\begin{array}{c}542 \\
(22.00)\end{array}$ & $\begin{array}{c}2,501 \\
(100.00)\end{array}$ & $\begin{array}{c}648 \\
(64.00)\end{array}$ & $\begin{array}{c}369 \\
(36.00)\end{array}$ & $\begin{array}{c}1,017 \\
(100.00)\end{array}$ \\
\hline Over-payers & $\begin{array}{c}463 \\
(31.89) \\
\end{array}$ & $\begin{array}{c}989 \\
(68.11) \\
\end{array}$ & $\begin{array}{c}1,452 \\
(100.00) \\
\end{array}$ & $\begin{array}{c}384 \\
(32.21) \\
\end{array}$ & $\begin{array}{c}808 \\
(67.79) \\
\end{array}$ & $\begin{array}{c}1,192 \\
(100.00) \\
\end{array}$ \\
\hline Total & $\begin{array}{c}2,422 \\
(61.00)\end{array}$ & $\begin{array}{c}1,531 \\
(38.73)\end{array}$ & $\begin{array}{c}3,953 \\
(100.00)\end{array}$ & $\begin{array}{c}1,032 \\
(46.72)\end{array}$ & $\begin{array}{c}1,177 \\
(53.28)\end{array}$ & $\begin{array}{c}2,209 \\
(100.00)\end{array}$ \\
\hline
\end{tabular}


Panel C. Default Probability (CHS)

\begin{tabular}{|c|c|c|c|c|c|c|}
\hline & \multicolumn{3}{|c|}{$\begin{array}{l}\text { Default Probability (CHS) } \\
\qquad I^{\text {st }} \text { Quintile }\end{array}$} & \multicolumn{3}{|c|}{$\begin{array}{l}\text { Default Probability (CHS) } \\
5^{\text {th }} \text { Quintile } \\
\end{array}$} \\
\hline & Under-payer & Over-payer & Total & Under-payer & Over-payer & Total \\
\hline Under-payer & $\begin{array}{c}2,203 \\
(80.84)\end{array}$ & $\begin{array}{c}522 \\
(19.16)\end{array}$ & $\begin{array}{c}2,725 \\
(100.00)\end{array}$ & $\begin{array}{c}559 \\
(61.90) \\
\end{array}$ & $\begin{array}{c}344 \\
(38.10)\end{array}$ & $\begin{array}{c}903 \\
(100.00)\end{array}$ \\
\hline Over-payer & $\begin{array}{c}463 \\
(41.16)\end{array}$ & $\begin{array}{c}662 \\
(58.84)\end{array}$ & $\begin{array}{c}1,125 \\
(100.00)\end{array}$ & $\begin{array}{c}402 \\
(31.43)\end{array}$ & $\begin{array}{c}877 \\
(68.57)\end{array}$ & $\begin{array}{c}1,279 \\
(100.00)\end{array}$ \\
\hline Total & $\begin{array}{c}2,666 \\
(69.25)\end{array}$ & $\begin{array}{c}1,184 \\
(30.75)\end{array}$ & $\begin{array}{c}3,850 \\
(100.00)\end{array}$ & $\begin{array}{c}961 \\
(44.04)\end{array}$ & $\begin{array}{c}1,221 \\
(55.96)\end{array}$ & $\begin{array}{c}2,182 \\
(100.00)\end{array}$ \\
\hline
\end{tabular}




\section{Table 9. Changes in future growth and risk}

This table presents the changes in growth and risk for all US-listed firms during 1975-2008. We exclude financial firms (SIC codes 6000-6999), utilities (SIC codes 4900-4949), and securities other than common stock. Firms are categorized as under-payers or over-payers based on the Midpoint classification (see Table 3). Panel A reports the average change in growth and risk from one year ahead (year +1 ) to five years ahead (year+5) for each of the three groups (i.e., non-payers, under-payers, and over-payers) for several variables used as proxies for firm growth and risk. Panel B reports the differences in changes between under-payers and over-payers. All variables are defined in the Appendix. t-statistics are reported in parentheses. $* * * * *$, and $*$ denote significance at $1 \%, 5 \%$, and $10 \%$, respectively.

\begin{tabular}{|c|c|c|c|c|c|c|c|c|c|c|c|c|c|c|c|}
\hline Panel A & & & n-payers & & & & & der-pay & & & & & ver-pay & & \\
\hline & $\begin{array}{c}\text { Year } \\
+1\end{array}$ & $\begin{array}{l}\text { Year } \\
+2\end{array}$ & $\begin{array}{c}\text { Year } \\
+3\end{array}$ & $\begin{array}{c}\text { Year } \\
+4\end{array}$ & $\begin{array}{c}\text { Year } \\
+5\end{array}$ & $\begin{array}{c}\text { Year } \\
+1\end{array}$ & $\begin{array}{c}\text { Year } \\
+2\end{array}$ & $\begin{array}{c}\text { Year } \\
+3\end{array}$ & $\begin{array}{c}\text { Year } \\
+4\end{array}$ & $\begin{array}{c}\text { Year } \\
+5\end{array}$ & $\begin{array}{c}\text { Year } \\
+1\end{array}$ & $\begin{array}{c}\text { Year } \\
+2\end{array}$ & $\begin{array}{c}\text { Year } \\
+3\end{array}$ & $\begin{array}{c}\text { Year } \\
+4\end{array}$ & $\begin{array}{c}\text { Year } \\
+5\end{array}$ \\
\hline $\begin{array}{l}\Delta \text { Total } \\
\text { Assets }\end{array}$ & 13.22 & 12.41 & 11.92 & 11.49 & 11.00 & 12.64 & 11.11 & 10.10 & 9.32 & 8.87 & 7.10 & 7.38 & 7.53 & 7.37 & 7.73 \\
\hline$\Delta$ Sales & 17.49 & 14.26 & 12.97 & 12.31 & 11.83 & 12.13 & 10.11 & 9.47 & 8.66 & 8.20 & 6.96 & 7.75 & 7.35 & 6.92 & 6.93 \\
\hline $\begin{array}{l}\Delta \mathrm{PPE} \\
\Delta\end{array}$ & 13.89 & 12.37 & 12.07 & 11.83 & 11.83 & 13.19 & 11.14 & 9.72 & 8.72 & 7.95 & 7.59 & 6.83 & 6.85 & 6.56 & 6.86 \\
\hline $\begin{array}{l}\text { Idiosyncratic } \\
\text { risk }\end{array}$ & 8.59 & 6.73 & 6.71 & 5.98 & 5.51 & 6.28 & 5.48 & 5.30 & 4.70 & 4.58 & 7.05 & 6.09 & 5.83 & 4.26 & 3.85 \\
\hline $\begin{array}{l}\Delta \text { Systematic } \\
\text { risk }\end{array}$ & 117.68 & 105.83 & 109.32 & 99.91 & 98.14 & 64.74 & 59.47 & 58.71 & 51.92 & 53.21 & 73.43 & 77.85 & 71.08 & 66.74 & 64.72 \\
\hline $\begin{array}{l}\Delta \text { Sigma } \\
\text { equity }\end{array}$ & 15.00 & 13.05 & 13.19 & 12.88 & 12.79 & 11.11 & 11.03 & 11.03 & 10.25 & 10.11 & 14.99 & 14.01 & 12.42 & 10.40 & 10.41 \\
\hline $\begin{array}{l}\Delta \text { Sigma } \\
\text { assets }\end{array}$ & 13.91 & 12.11 & 12.16 & 11.94 & 11.92 & 9.42 & 9.56 & 9.87 & 9.10 & 9.17 & 13.65 & 13.04 & 11.48 & 9.81 & 9.97 \\
\hline
\end{tabular}




\begin{tabular}{|c|c|c|c|c|c|c|c|}
\hline \multirow[t]{2}{*}{ Panel B. } & \multicolumn{7}{|c|}{ Differences in means: Over-payers vs Under-payers } \\
\hline & $\Delta$ Total assets & $\Delta$ Sales & $\triangle \mathrm{PPE}$ & $\begin{array}{c}\Delta \text { Idiosyncratic } \\
\text { risk }\end{array}$ & $\Delta$ Systematic risk & $\Delta$ Sigma equity & $\Delta$ Sigma assets \\
\hline Year +1 & $\begin{array}{c}-5.540 * * * \\
(-19.70)\end{array}$ & $\begin{array}{c}-5.168 * * * \\
(-18.84)\end{array}$ & $\begin{array}{c}-5.596 * * * \\
(-16.07)\end{array}$ & $\begin{array}{c}0.772 * * \\
(2.14)\end{array}$ & $\begin{array}{c}8.692 * * * \\
(2.88)\end{array}$ & $\begin{array}{c}3.877 * * * \\
(6.68)\end{array}$ & $\begin{array}{c}4.238 * * * \\
(7.55)\end{array}$ \\
\hline Year +2 & $\begin{array}{c}-3.726 * * * \\
(-13.06)\end{array}$ & $\begin{array}{c}-2.355^{* * *} * \\
(-8.74)\end{array}$ & $\begin{array}{c}-4.313 * * * \\
(-12.45)\end{array}$ & $\begin{array}{l}0.606 \\
(1.61)\end{array}$ & $\begin{array}{c}18.38 * * * \\
(6.00)\end{array}$ & $\begin{array}{c}2.973 * * * \\
(4.98)\end{array}$ & $\begin{array}{c}3.483 * * * \\
(6.01)\end{array}$ \\
\hline Year +3 & $\begin{array}{c}-2.574 * * * \\
(-8.83)\end{array}$ & $\begin{array}{c}-2.121 * * * \\
(-7.89)\end{array}$ & $\begin{array}{c}-2.868 * * * \\
(-8.16)\end{array}$ & $\begin{array}{l}0.535 \\
(1.38)\end{array}$ & $\begin{array}{c}12.36 * * * \\
(4.06)\end{array}$ & $\begin{array}{c}1.390 * * \\
(2.28)\end{array}$ & $\begin{array}{l}1.603 * * * \\
(2.70)\end{array}$ \\
\hline Year +4 & $\begin{array}{c}-1.952 * * * \\
(-6.74)\end{array}$ & $\begin{array}{c}-1.732 * * * \\
(-6.46)\end{array}$ & $\begin{array}{c}-2.160 * * * \\
(-6.21)\end{array}$ & $\begin{array}{l}-0.439 \\
(-1.12)\end{array}$ & $\begin{array}{c}14.82 * * * \\
(4.79)\end{array}$ & $\begin{array}{l}0.144 \\
(0.23)\end{array}$ & $\begin{array}{l}0.706 \\
(1.16)\end{array}$ \\
\hline Year +5 & $\begin{array}{c}-1.138 * * * \\
(-3.78)\end{array}$ & $\begin{array}{c}-1.268 * * * \\
(-4.56)\end{array}$ & $\begin{array}{c}-1.093 * * * \\
(-3.06)\end{array}$ & $\begin{array}{l}-0.725 * \\
(-1.81)\end{array}$ & $\begin{array}{c}11.51 * * * \\
(3.56)\end{array}$ & $\begin{array}{l}0.306 \\
(0.48)\end{array}$ & $\begin{array}{l}0.806 \\
(1.28)\end{array}$ \\
\hline
\end{tabular}




\section{Table 10. Over-payers and under-payers: Sample overview}

This table presents summary statistics for the reduced sample of over-payers and under-payers (i.e., excluding non-payers) based on the Mid-point classification (see Table 3), which is used for the regression analyses of the determinants of the likelihood to over-pay in Tables 11 and 12. We use firmlevel data for all US-listed firms during 1981-2008. We exclude financial firms (SIC codes 6000-6999), utilities (SIC codes 4900-4949), and securities other than common stock. Panel A reports an array of alternative financial distress and firm survival measures. Firm survival measures are computed over the five years following the current period (t). Panel B reports the institutional ownership variables. All variables are defined in the Appendix.

\begin{tabular}{lcccc}
\hline Panel A. Financial Distress and Firm Survival & & & & \\
\hline & $\mathrm{N}$ & Mean & Median & St. Dev. \\
Interest coverage & 23,656 & 2.304 & 2.077 & 1.028 \\
Z-Score - Dummy & 27,619 & 0.916 & 1.000 & 0.278 \\
Zmijewski-score & 27,619 & -1.570 & -1.641 & 1.403 \\
O-score & 27,619 & -4.623 & -4.719 & 1.959 \\
Default probability & 27,619 & 3.650 & 0.000 & 14.186 \\
Default probability (CHS) & 27,619 & 0.692 & 0.038 & 5.694 \\
Merger and acquisition (year +5) & 27,619 & 0.208 & 0.000 & 0.406 \\
Exchange transaction (year +5) & 27,619 & 0.011 & 0.000 & 0.102 \\
Liquidation (year +5) & 27,619 & 0.002 & 0.000 & 0.039 \\
Exchange dropped (year +5) & 27,619 & 0.065 & 0.000 & 0.246 \\
Liquidation and Exchange dropped (year +5) & 27,619 & 0.066 & 0.000 & 0.248 \\
Bankruptcy (year +5) & 27,619 & 0.033 & 0.000 & 0.180 \\
\hline & & & & \\
Panel B. Institutional Ownership & & & & \\
\hline Institutional ownership & 27,619 & 0.413 & 0.402 & 0.267 \\
Investor turnover & 27,619 & 0.189 & 0.188 & 0.053 \\
Low turnover institutional ownership & 27,619 & 0.078 & 0.059 & 0.074 \\
Ownership of dedicated institutions & 27,619 & 0.056 & 0.032 & 0.067 \\
Ownership of quasi-indexer institutions & 27,619 & 0.274 & 0.264 & 0.183 \\
\hline
\end{tabular}




\section{Table 11. Determinants of overpayment.}

This table presents logit regression results on a panel dataset of all US-listed firms in our sample during 1981-2008. We exclude financial firms (SIC codes 6000-6999), utilities (SIC codes 4900-4949), and securities other than common stock. The dependent variable is a binary variable that takes the value of one if firm $i$ at year $t$ is identified as an over-payer and zero if it is identified as an under-payer based on the Mid-point classification (see Table 3). The independent variables are a set of institutional ownership variables. All variables are defined in the Appendix. Regressions include industry and year controls. Industries are defined using the Fama-French 49 industries classification. We use heteroskedasticity robust standard errors clustered by firm to control for within-firm (serial) correlation. Marginal effects are reported in brackets and robust standard errors are reported in parentheses. $* * *, * *$, and * denote significance at $1 \%, 5 \%$, and $10 \%$, respectively.

\begin{tabular}{|c|c|c|c|c|}
\hline & (1) & (2) & (3) & (4) \\
\hline & & Over-pay & dummy & \\
\hline Institutional ownership & $-0.969 * * *$ & $-0.910 * * *$ & $-1.209 * * *$ & $-2.450 * * *$ \\
\hline & {$[-0.230]$} & {$[-0.215]$} & {$[-0.286]$} & {$[-0.578]$} \\
\hline & $(0.082)$ & $(0.083)$ & $(0.094)$ & $(0.230)$ \\
\hline Investor turnover & & $-1.777 * * *$ & & \\
\hline & & {$[-0.420]$} & & \\
\hline & & $(0.309)$ & & \\
\hline Low turnover institutional ownership & & & $1.496^{* * *}$ & \\
\hline & & & {$[0.354]$} & \\
\hline & & & $(0.330)$ & \\
\hline Ownership of dedicated institutions & & & & $1.579 * * *$ \\
\hline & & & & {$[0.373]$} \\
\hline & & & & $(0.372)$ \\
\hline Ownership of quasi-indexer institutions & & & & $1.993 * * *$ \\
\hline & & & & {$[0.470]$} \\
\hline & & & & $(0.298)$ \\
\hline Constant & $-0.821 * *$ & -0.609 & $-0.861 * *$ & $-0.840 * *$ \\
\hline & $(0.364)$ & $(0.375)$ & $(0.375)$ & $(0.370)$ \\
\hline Industry \& Year dummies & YES & YES & YES & YES \\
\hline Observations & 27,619 & 27,619 & 27,619 & 27,619 \\
\hline Pseudo $\mathrm{R}^{2}$ & 0.018 & 0.020 & 0.019 & 0.020 \\
\hline
\end{tabular}




\section{Table 12. Robustness Test: Financial Distress as determinant for overpayment}

This table presents the results on the determinants of overpayment using alternative specifications, which control for financial distress, on a panel dataset of all US-listed firms in our sample during 1981-2008. We exclude financial firms (SIC codes 6000-6999), utilities (SIC codes 4900-4949), and securities other than common stock. Panel A presents the estimates from logit regression results where the dependent variable is a binary variable that takes the value of one if firm $i$ at year $t$ is identified as an over-payer and zero if it is identified as an under-payer based on the Mid-point classification (see Table 3). The independent variables are a distress measure (the Default probability) and a set of institutional ownership variables. Panels $\mathrm{B}$ and $\mathrm{C}$ address the potential endogeneity of financial distress using an instrumental variable probit approach. Model (1) reports the first stage regression on firm financial distress. The instrumental variable in Panel B is the annual average industry financial distress (excluding the default probability of firm $i$, for each firm-year observation) whereas the instrumental variable in Panel $\mathrm{C}$ is the annual industry-wide economic distress. Models (2) to (5) report the second stage probit regression on the likelihood to overpay. All variables are defined in the Appendix. All regressions include industry and year controls. Industries are defined using the Fama-French 49 industries classification. We use heteroskedasticity robust standard errors clustered by firm to control for within-firm (serial) correlation. Robust standard errors are reported in parentheses. $* * *, * *$, and * denote significance at $1 \%, 5 \%$, and $10 \%$, respectively.

\begin{tabular}{|c|c|c|c|c|}
\hline \multicolumn{5}{|c|}{ Panel A. Exogenous Financial Distress } \\
\hline & (1) & (2) & (3) & (4) \\
\hline & \multicolumn{4}{|c|}{ Over-payers dummy } \\
\hline Institutional ownership & $\begin{array}{c}-0.853 * * * \\
(0.083)\end{array}$ & $\begin{array}{c}-0.793 * * * \\
(0.084)\end{array}$ & $\begin{array}{c}-1.093 * * * \\
(0.095)\end{array}$ & $\begin{array}{c}-2.383 * * * \\
(0.232)\end{array}$ \\
\hline Investor turnover & & $\begin{array}{c}-1.782 * * * \\
(0.312)\end{array}$ & & \\
\hline $\begin{array}{l}\text { Low turnover institutional } \\
\text { ownership }\end{array}$ & & & $\begin{array}{c}1.500 * * * \\
(0.332)\end{array}$ & \\
\hline $\begin{array}{l}\text { Ownership of dedicated } \\
\text { institutions }\end{array}$ & & & & $\begin{array}{c}1.577 * * * \\
(0.373)\end{array}$ \\
\hline $\begin{array}{l}\text { Ownership of quasi-indexer } \\
\text { institutions }\end{array}$ & & & & $\begin{array}{c}2.075^{* * * *} \\
(0.299)\end{array}$ \\
\hline Default probability & $\begin{array}{c}0.014 * * * \\
(0.001)\end{array}$ & $\begin{array}{c}0.014 * * * \\
(0.001)\end{array}$ & $\begin{array}{l}0.014 * * * \\
(0.001)\end{array}$ & $\begin{array}{c}0.014 * * * \\
(0.001)\end{array}$ \\
\hline Constant & $\begin{array}{c}-0.856^{* *} \\
(0.356)\end{array}$ & $\begin{array}{c}-0.644 * \\
(0.367)\end{array}$ & $\begin{array}{c}-0.897 * * \\
(0.368)\end{array}$ & $\begin{array}{c}-0.873 * * \\
(0.360)\end{array}$ \\
\hline Industry \& Year dummies & YES & YES & YES & YES \\
\hline Observations & 27,619 & 27,619 & 27,619 & 27,619 \\
\hline Pseudo $\mathrm{R}^{2}$ & 0.024 & 0.026 & 0.025 & 0.027 \\
\hline
\end{tabular}




\begin{tabular}{|c|c|c|c|c|c|}
\hline \multicolumn{6}{|c|}{ Panel B. Endogenous Financial Distress - Industry average distress } \\
\hline & $(1)$ & $(2)$ & (3) & $(4)$ & $(5)$ \\
\hline & \multicolumn{5}{|c|}{ Over-payers dummy } \\
\hline Institutional ownership & $\begin{array}{c}-8.690 * * * \\
(0.485)\end{array}$ & $\begin{array}{c}-0.256^{* * * *} \\
(0.071)\end{array}$ & $\begin{array}{c}-0.226 * * * \\
(0.070)\end{array}$ & $\begin{array}{c}-0.389 * * * \\
(0.079)\end{array}$ & $\begin{array}{c}-1.209 * * * \\
(0.149)\end{array}$ \\
\hline Investor turnover & & & $\begin{array}{c}-0.989 * * * \\
(0.192)\end{array}$ & & \\
\hline $\begin{array}{l}\text { Low turnover institutional } \\
\text { ownership }\end{array}$ & & & & $\begin{array}{c}0.829 * * * \\
(0.200)\end{array}$ & \\
\hline $\begin{array}{l}\text { Ownership of dedicated } \\
\text { institutions }\end{array}$ & & & & & $\begin{array}{c}0.872 * * * \\
(0.221)\end{array}$ \\
\hline $\begin{array}{l}\text { Ownership of quasi-indexer } \\
\text { institutions }\end{array}$ & & & & & $\begin{array}{c}1.302 * * * \\
(0.175)\end{array}$ \\
\hline Default probability & & $\begin{array}{c}0.035 * * * \\
(0.004)\end{array}$ & $\begin{array}{c}0.035 * * * \\
(0.004)\end{array}$ & $\begin{array}{c}0.035^{* * *} \\
(0.004)\end{array}$ & $\begin{array}{c}0.034 * * * \\
(0.004)\end{array}$ \\
\hline Industry average distress & $\begin{array}{l}0.449 * * * \\
(0.043)\end{array}$ & & & & \\
\hline Constant & $\begin{array}{l}2.155 \\
(1.681)\end{array}$ & $\begin{array}{c}-0.554 * * * \\
(0.187)\end{array}$ & $\begin{array}{c}-0.435^{* *} \\
(0.194)\end{array}$ & $\begin{array}{c}-0.574 * * * \\
(0.193)\end{array}$ & $\begin{array}{c}-0.562 * * * \\
(0.186)\end{array}$ \\
\hline $\begin{array}{l}\text { Industry \& Year dummies } \\
\text { Observations } \\
\text { p-value Wald exogeneity test }\end{array}$ & $\begin{array}{c}\text { YES } \\
27,605 \\
0.000 \\
\end{array}$ & $\begin{array}{c}\text { YES } \\
27,605 \\
0.000 \\
\end{array}$ & $\begin{array}{c}\text { YES } \\
27,605 \\
0.000 \\
\end{array}$ & $\begin{array}{c}\text { YES } \\
27,605 \\
0.000 \\
\end{array}$ & $\begin{array}{c}\text { YES } \\
27,605 \\
0.000 \\
\end{array}$ \\
\hline \multicolumn{6}{|c|}{ Panel C. Endogenous Financial Distress - Industry economic distress } \\
\hline \multirow[t]{2}{*}{ 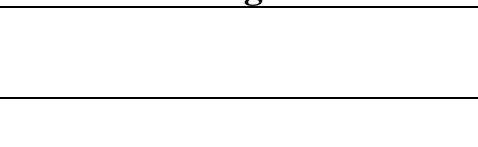 } & $(1)$ & $(2)$ & $(3)$ & $(4)$ & $(5)$ \\
\hline & \multicolumn{5}{|c|}{ Over-payers dummy } \\
\hline Institutional ownership & $\begin{array}{c}-8.728 * * * \\
(0.484)\end{array}$ & $\begin{array}{c}-0.288 * * * \\
(0.104)\end{array}$ & $\begin{array}{c}-0.254 * * \\
(0.103)\end{array}$ & $\begin{array}{c}-0.421 * * * \\
(0.114)\end{array}$ & $\begin{array}{c}-1.231 * * * \\
(0.177)\end{array}$ \\
\hline Investor turnover & & & $\begin{array}{l}-1.006 * * * \\
(0.198)\end{array}$ & & \\
\hline $\begin{array}{l}\text { Low turnover institutional } \\
\text { ownership }\end{array}$ & & & & $\begin{array}{c}0.844 * * * \\
(0.204)\end{array}$ & \\
\hline $\begin{array}{l}\text { Ownership of dedicated } \\
\text { institutions }\end{array}$ & & & & & $\begin{array}{c}0.882 * * * \\
(0.227)\end{array}$ \\
\hline $\begin{array}{l}\text { Ownership of quasi-indexer } \\
\text { institutions }\end{array}$ & & & & & $\begin{array}{c}1.305^{* * *} \\
(0.176)\end{array}$ \\
\hline Default probability & & $\begin{array}{c}0.032 * * * \\
(0.008)\end{array}$ & $\begin{array}{c}0.033 * * * \\
(0.008)\end{array}$ & $\begin{array}{c}0.033 * * * \\
(0.008)\end{array}$ & $\begin{array}{c}0.033 * * * \\
(0.008)\end{array}$ \\
\hline Industry economic distress & $\begin{array}{l}5.886 * * * \\
(0.946)\end{array}$ & & & & \\
\hline Constant & $\begin{array}{l}2.315 \\
(1.612)\end{array}$ & $\begin{array}{c}-0.555^{* * *} \\
(0.190)\end{array}$ & $\begin{array}{c}-0.435 * * \\
(0.197)\end{array}$ & $\begin{array}{c}-0.576 * * * \\
(0.197)\end{array}$ & $\begin{array}{c}-0.564 * * * \\
(0.189)\end{array}$ \\
\hline Industry \& Year dummies & YES & YES & YES & YES & YES \\
\hline Observations & 27,619 & 27,619 & 27,619 & 27,619 & 27,619 \\
\hline p-value Wald exogeneity test & 0.005 & 0.005 & 0.005 & 0.005 & 0.005 \\
\hline
\end{tabular}

